\title{
Dynamic forcing of coastal plankton by nutrient imbalances and match-mismatch between nutrients and turbulence
}

\author{
Estela Romero $^{1,2, *}$, Francesc Peters ${ }^{1}$, Cèlia Marrasé ${ }^{1}$ \\ ${ }^{1}$ Institut de Ciències del Mar (CSIC), 08003 Barcelona, Catalunya, Spain \\ ${ }^{2}$ Present address: UMR 7619 Sisyphe, CNRS-Université Pierre et Marie Curie, 75005 Paris, France
}

\begin{abstract}
We carried out 2 experimental simulations in which natural planktonic communities were subjected to a combination of turbulence and variable nutrient forcing. Nutrient addition was varied both in terms of total nutrient load and in the balance of elements. Unbalanced nutrient inputs (with regard to Redfield values) and varying nitrogen sources are frequent in coastal areas heavily exposed to human perturbations. The relative abundance of nitrate and ammonium has been related to shifts in the size distribution of the planktonic community, so we explored whether uneven inputs of ammonium and nitrate could be major factors driving plankton dynamics in coastal environments. The occasional uncoupling between turbulence and nutrient pulses is also a distinctive feature of nearshore waters compared with open ocean environments. Thus, we further tested the match-mismatch between nutrient enrichments and turbulent mixing. Both turbulence and nutrient inputs had a significant positive effect on the growth of planktonic organisms, with some synergistic effects. Shifts in community composition appeared to be mostly related to the interplay between turbulence and $\mathrm{N}$ partitioning. Under still conditions, ammonium-rich waters favoured small organisms and reinforced the microbial loop, whereas nitrate mostly favoured diatom growth. Turbulence added complexity to the final outcome, because mixing tended to favour large over small osmotrophs. Accordingly, the rapid growth of small autotrophs and heterotrophic bacteria in ammonium-rich waters may be partly counteracted by diatom increases if nutrient pulses are coupled with turbulent mixing; diatom bursts after nitrate enrichments may also be enhanced by concomitant turbulence.
\end{abstract}

KEY WORDS: Eutrophication $\cdot$ Mediterranean Sea $\cdot$ Nitrate $\cdot$ Ammonium $\cdot$ Plankton $\cdot$ Experimental simulation $\cdot$ Coastal areas

\section{INTRODUCTION}

There is ample evidence that turbulence, i.e. fluctuations in flow, affects oceanic production. Basically, increased mixing brings generally scarce nutrients in closer contact with phytoplankton, at the macroscale but also at the microscale, where cells can use the nutrients to grow. Evidence has been built since the 1970s (Margalef 1978) with theoretical developments (Lazier \& Mann 1989, Karp-Boss et al. 1996), field observations (Horne et al. 1996, Lévy 2008), mesocosm experiments (Howarth et al. 1993, Nerheim et al. 2002, Iversen et al. 2010), microcosm experiments (Estrada et al. 1988, Peters et al. 2002) and modelling (e.g. Allen et al. 2004 and references therein). Diatoms, especially the larger ones, seem to be clearly favoured by the combination of turbulence and increased nutrient load (Arin et al. 2002, Cózar \& Echevarría 2005, Peters et al. 2006, Guadayol et al. 2009). This is because the enhancement of nutrient 
flux towards the cells by turbulence is dependent on cell size (Lazier \& Mann 1989, Karp-Boss et al. 1996) and on the particular life-form characteristics of diatoms. The effects of turbulent mixing on population and community dynamics, however, are not always transferred to ecosystem-level properties, as observed by Petersen et al. (1998), and large-scale shifts may be dependent on the specific structure of particular ecosystems.

Most observations and experiments have an open ocean focus influenced by concepts that are relevant for global biogeochemical cycles, such as new production and the export of organic matter, and hence mostly focus on nitrogen as the limiting element and nitrate as the driving nutrient. However, phytoplankton can use other forms of nitrogen, such as ammonium, dinitrogen gas or nitrogen bound in organic matter (DON). Indeed, ammonium has classically been considered an important $\mathrm{N}$ source for phytoplankton, even the preferred one (Syrett 1981). Ammonium is not an uncommon addition in mesocosm experiments (e.g. Petersen et al. 1998) and is regularly included in models (Fasham et al. 1990, Baretta et al. 1995, Lancelot et al. 2005). Nevertheless, ammonium is mostly internally recycled in models and not often used as a system forcing factor.

Further, not all N compounds can be used by all phytoplanktonic organisms; affinities for specific nutrients vary among groups. There is abundant evidence that small autotrophic cells and bacteria have a preference for ammonium, whilst larger phytoplankton tend to prefer nitrate (Eppley et al. 1969, Le Bouteiller 1986, Wheeler \& Kirchman 1986, Dortch 1990, Stolte et al. 1994, Riegman \& Noordeloos 1998). Notably, large diatoms prefer nitrate over ammonium (e.g. Stolte et al. 1994, Lomas \& Glibert 1999) and this conforms to the idea that these organisms take the most advantage of the increased nitrate level after winter mixing in most oceanic regions.

The issue of varying $\mathrm{N}$ sources and the differential effect on phytoplankton groups is of major concern in coastal areas, because natural factors and anthropogenic activities on land strongly affect both the total load and the relative composition of freshwater inputs reaching coastal waters. In this regard, land use is a key factor in predicting the potential burdens of human activities: while agriculture is responsible for large spills of nitrate, urban waste waters contain high concentrations of ammonium and phosphate (European Environment Agency 1999, 2001). As a result, large gradients in the relative proportion of nutrient elements can be found across nearby coastal sites.
In addition to the diversity of nutrient sources, a challenging feature of coastal regions is the temporal mismatch between turbulence and nutrient inputs. In many open ocean regions, seasonality dominates annual nutrient fluxes, which are tightly linked to mixing and turbulence. Cooling of surface waters causes mixing of the water column and hence favours a bulk inflow of nutrients from deeper layers. During warm periods, however, surface waters warm up and stratify, so that there is a very limited nutrient exchange with the bottom waters. Accordingly, nutrient-rich periods tend to coincide with increased turbulence (Margalef 1978, Longhurst 1995). In coastal areas, this temporary coupling does not always occur: during the cold season, mixing of the water column does indeed supply new nutrients to the surface, but additional nutrient pulses due to anthropogenic activities may occur throughout the year. Consequently, organisms can experience low turbulence intensities and benefit from high nutrient concentrations, or they can undergo strong turbulent motion uncoupled from the main seasonal mixing and nutrient input (Cloern 1996). Unlike the wellstudied ecological implications described for the rich-turbulent vs. poor-calm dichotomy (in terms of dominant planktonic groups and community dynamics; Margalef 1978, Smetacek 1985), the biological shifts linked to alternative conditions are uncertain.

Overall, the interplay between turbulence, nutrient load and $\mathrm{N}$ partitioning may affect the community in several ways, because all 3 factors can select for specific groups and size classes. Whether contrasting biological response patterns found in coastal locations can be explained by this asymmetry is not fully understood yet, partly due to the difficulty of finding coherent trends entangled within a matrix of high variability in coastal ecosystems (Cloern \& Jassby 2008). Nonetheless, a better understanding is required of the outcome of this combined forcing, because changes in plankton community composition entail shifts in broader processes such as energy transfer to higher trophic levels, benthic-pelagic coupling, or the stimulation of harmful algal blooms (Bronk et al. 2007). Further insights are also desirable for practical management purposes, particularly in areas receiving high nutrient loads with variable composition.

To address these issues, we report 2 experiments with seawater from the Barcelona (Spain) coastal area. In order to mimic episodic nutrient inflows, we amended this water with varying concentrations of ammonium and nitrate. Additionally, the planktonic community was subjected to turbulence. Turbulence 
allowed us to simulate the effects of breezes and meteorological fronts in the coastal area and to compare them with the effects of enrichments under calm-water conditions. The experiments were performed in autumn and spring, at times when fronts tend to be most frequent in the area (Martin-Vide 1982, Llasat \& Puigcerver 1997, Guadayol \& Peters 2006).

Our objectives were twofold: (1) to explore the differential biological response to nutrient enrichments featuring diverse proportions of $\mathrm{N}$ compounds, i.e. ammonium and nitrate, simulating the gradients observed in natural systems as a result of anthropogenic perturbations; and (2) to study the variability in the dynamics of planktonic organisms related to the match-mismatch of turbulence and episodic nutrient inputs. Our hypothesis was that the effect of turbulence on phytoplankton growth would increase with the relative amount of nitrate present, since this is the preferred $\mathrm{N}$ source of the larger phytoplankton, and the increase of nutrient flux towards the cells owing to turbulence is size dependent.

\section{MATERIALS AND METHODS}

\section{Study area and experimental setup}

Sea water for the experiments was collected ca. $0.5 \mathrm{~km}$ offshore of Barcelona's coast $\left(41^{\circ} 22.91^{\prime} \mathrm{N}\right.$, $\left.2^{\circ} 11.97^{\prime} \mathrm{E}\right)$. This area is strongly sensitive to freshwater inputs owing to the proximity of the Besòs and Llobregat rivers and storm sewer overflows; during events of intense rainfall, excess rainwater is collected and channelled to the sea through these coastal pipelines. Liquete et al. (2007) provide a thorough review of the main geological, hydrographic and oceanographical features of the Barcelona continental shelf.

We aimed for a series of nutrient additions that could push the system towards an extreme, though realistic, situation, so to design the amendments, a brief analysis of the nutrient climatology and the previous conditions was performed before starting the experiments. Interannual surveys (1997-2008) of the nearshore waters between 0.5 and $2 \mathrm{~km}$ from the coastline showed ammonium concentrations between 0.02 and $9.3 \mu \mathrm{mol} \mathrm{l}{ }^{-1}$ with a median of $1.4 \mathrm{~mol}$ $1^{-1}$, and nitrate concentrations between 0.07 and $7.6 \mu \mathrm{mol} \mathrm{l}^{-1}$ with a median of $0.9 \mu \mathrm{mol} \mathrm{l}^{-1}$. Ratios of $\mathrm{NH}_{4}{ }^{+}$to $\mathrm{NO}_{3}{ }^{-}$ranged from 0.05 to 8 with a median of 1.7, reflecting the anthropogenic influence on the area. The highest $\mathrm{NH}_{4}{ }^{+}: \mathrm{NO}_{3}{ }^{-}$occurred in late spring
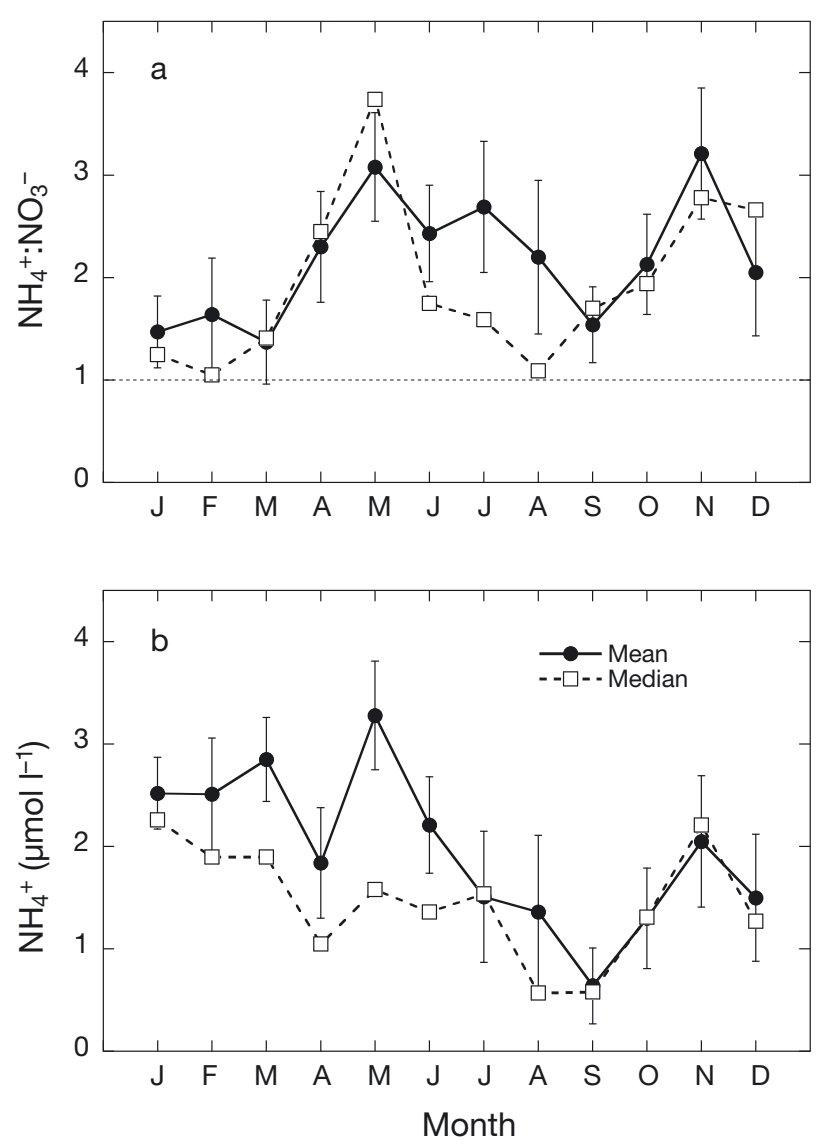

Fig. 1. Monthly climatological means ( $\pm 1 \mathrm{SE}$ ) and medians of $\mathrm{NH}_{4}{ }^{+}: \mathrm{NO}_{3}{ }^{-}$and of $\mathrm{NH}_{4}{ }^{+}$for the Barcelona coast (1997-2008). Data were from surface waters from a water column depth similar to that used for sampling our experimental water ( 1-2 m depth). Data sources: the Catalan Water Agency (ACA, http://aca-web.gencat.cat/aca) and our laboratory's Coastal Ocean Observatory (COO, http://coo.icm.csic.es)

and in autumn (Fig. 1). High ratios in spring were fueled not only by the recycling of the organic matter produced during the typical winter-spring bloom but also to the storm overflows that increased the anthropogenic footprint during storm events. In autumn, although mixing brought in some nitrate, ammonium tended to dominate and was derived from the mostly heterotrophic microbial-dominated summer season and again from inputs after rainfall storms through runoff. Spring and autumn were the seasons with the highest storm activity in the area and thus tended to show the largest variability in ambient conditions.

During Expt 1 in November 2005, seawater showed high concentrations of nitrate and phosphate, and stoichiometric ratios were close to Redfield values $(\mathrm{N}: \mathrm{P} \approx 16)$. Intense rainfall episodes and subsequent terrestrial runoff are rather frequent in autumn, and 
can result in high inputs of nutrients. Accordingly, we added nitrate and ammonium to reach a final concentration of $10 \mu \mathrm{mol} \mathrm{l}^{-1} \mathrm{~N}$, distributed in 2 ways: (1) even amounts of nitrate and ammonium (5 $\mu \mathrm{mol}$ $\mathrm{l}^{-1} \mathrm{NH}_{4}^{+}+5 \mu_{\mathrm{mol} \mathrm{l}} \mathrm{l}^{-1} \mathrm{NO}_{3}^{-}$) and the corresponding Redfield quantities of phosphate and silicate (Nit tanks); (2) excess ammonium (9 $\mu \mathrm{mol} \mathrm{l} \mathrm{l}^{-1} \mathrm{NH}_{4}{ }^{+}+$ $0.9 \mu \mathrm{mol} \mathrm{l} l^{-1} \mathrm{NO}_{3}{ }^{-}$), to reach a final $\mathrm{NH}_{4}{ }^{+}: \mathrm{NO}_{3}{ }^{-}$ratio of $\sim$ 10:1 and the corresponding Redfield quantities of phosphate and silicate, simulating spills containing urban wastewater (Am tanks). For Expt 2 (April 2006), total nutrient load was low, ammonium exceeded nitrate and element ratios departed from Redfield values $(\mathrm{N}: \mathrm{P} \approx 28)$. Thus, to induce changes in the community, we designed 4 amendments. We counteracted the initial lack of phosphate and silicate by adding both these nutrients in excess with regard to $\mathrm{N}$ inputs (Am tanks); other tanks received silicate and phosphate, and additional nitrate (Nit and Nit2 tanks); finally, 2 tanks were enriched with phosphate, silicate, nitrate and ammonium (Am2 tanks).

All nutrient enrichments were done as a single addition at the beginning of the experiment. In both experiments, some tanks remained unenriched and were kept as controls (Ctrl). Further, to assess the match-mismatch with turbulent mixing, half the tanks in each treatment were subjected to turbulence

Table 1. Summary of experimental conditions. Different amounts of nutrients were added to the tanks to reach the final concentrations below; Am, Am2: ammonium-rich; Nit, Nit2: nitrate-rich; S: still; T: turbulent. Control tanks (Crtl) remained unenriched

\begin{tabular}{|c|c|c|c|c|c|c|}
\hline \multirow[t]{2}{*}{ Code } & \multirow{2}{*}{\multicolumn{2}{|c|}{$\begin{array}{l}\text { Treat- Turbu- } \\
\text { ment lence }\end{array}$}} & \multicolumn{4}{|c|}{ Nutrient conc. $\left(\mu \mathrm{mol} \mathrm{l}{ }^{-1}\right)$} \\
\hline & & & $\mathrm{PO}_{4}{ }^{3-}$ & $\mathrm{H}_{4} \mathrm{SiO}_{4}$ & $\mathrm{NH}_{4}^{+}$ & $\mathrm{NO}_{3}^{-}$ \\
\hline \multicolumn{7}{|c|}{ Expt 1 (autumn; photoperiod 7:30-17:30 h, temp. $15^{\circ} \mathrm{C}$ ) } \\
\hline CtrlS & Ctrl & $\mathrm{S}$ & - & - & - & - \\
\hline CtrlT & Ctrl & $\mathrm{T}$ & - & - & - & - \\
\hline AmS & Am & $\mathrm{S}$ & 0.6 & 10 & 9.1 & 0.9 \\
\hline $\mathrm{AmT}$ & Am & $\mathrm{T}$ & 0.6 & 10 & 9.1 & 0.9 \\
\hline NitS & Nit & $\mathrm{S}$ & 0.6 & 10 & 5 & 5 \\
\hline NitT & Nit & $\mathrm{T}$ & 0.6 & 10 & 5 & 5 \\
\hline \multicolumn{7}{|c|}{ Expt 2 (spring; photoperiod 7:00-20:45 h, temp. $15^{\circ} \mathrm{C}$ ) } \\
\hline CtrlS & $\mathrm{Ctrl}$ & $\mathrm{S}$ & - & - & - & - \\
\hline CtrlT & Ctrl & $\mathrm{T}$ & - & - & - & - \\
\hline $\mathrm{AmS}$ & $\mathrm{Am}$ & $\mathrm{S}$ & 0.5 & 8 & - & - \\
\hline $\mathrm{AmT}$ & $\mathrm{Am}$ & $\mathrm{T}$ & 0.5 & 8 & - & - \\
\hline NitS & Nit & $\mathrm{S}$ & 0.5 & 8 & - & 4 \\
\hline NitT & Nit & $\mathrm{T}$ & 0.5 & 8 & - & 4 \\
\hline $\mathrm{Nit}^{2} \mathrm{~S}^{\mathrm{a}}$ & Nit2 & $\mathrm{S}$ & 1 & 16 & - & 4 \\
\hline $\mathrm{Nit} \mathrm{T}^{\mathrm{a}}$ & Nit2 & $\mathrm{T}$ & 1 & 16 & - & 4 \\
\hline $\mathrm{AmS} 2^{\mathrm{a}}$ & $\mathrm{Am} 2$ & $\mathrm{~S}$ & 1 & 16 & 2 & 2 \\
\hline $\mathrm{AmS} 2^{\mathrm{a}}$ & $\mathrm{Am} 2$ & $\mathrm{~T}$ & 1 & 16 & 2 & 2 \\
\hline
\end{tabular}

(T) and half were kept still (S). All treatments were done in duplicate except for 2 combinations in spring (Am2, Nit2), which could not be replicated due to logistical constraints. A scheme of all experimental conditions is shown in Table 1.

Small-scale turbulence was generated by means of vertically-oscillating grids (see Peters et al. 2002). We applied a turbulent kinetic energy dissipation rate $(\varepsilon)$ of approx. $10^{-3} \mathrm{~cm}^{2} \mathrm{~s}^{-3}$, in accordance with Peters \& Gross (1994). Turbulence conditions were slightly readjusted daily to correct for changes in water volume, as described in Guadayol et al. (2009). This turbulence intensity is within the range of typical values for coastal areas (Kiørboe \& Saiz 1995). These conditions simulate moderate windy episodes during the passage of meteorological fronts, but not storms. Intense storms that entail high water column turbulence, high bottom shear stress and often lead to resuspension events were not the object of this study. To focus on community shifts directly related to varying nutrient inputs, and to avoid indirect ecosystem effects, we set a maximum duration of $3 \mathrm{~d}$ for both experiments. A length of $3 \mathrm{~d}$ is also a likely duration for episodic events of this turbulence magnitude in this part of the coast (Guadayol \& Peters 2006). Temperature was adjusted to the in situ water temperature $\left(15^{\circ} \mathrm{C}\right.$ in both experiments $)$ and light conditions were set to $225 \mu \mathrm{mol}$ photons $\mathrm{m}^{-2}$ $\mathrm{s}^{-1}$ inside the containers, approximately the saturating irradiance reported for this system during most of the year (Satta et al. 1996). Photoperiod was also adjusted for the time of year (Table 1). Experiments were started within $1 \mathrm{~h}$ of water collection.

\section{Water sampling and analytical procedures}

We sampled subsurface water over a depth of ca. $15 \mathrm{~m}$. The water was screened with $150 \mu \mathrm{m}$ nylon mesh to remove large zooplankton, then transferred to 201 plastic carboys that had previously been washed with a dilute solution of sodium hypochlorite and rinsed with milli-Q water and sample water. Carboys were protected from sunlight and taken to the laboratory within 20 min of collection. In the laboratory, 151 cylindrical methacrylate containers were filled and subjected to experimental conditions in a light and temperature controlled environmental chamber for $3 \mathrm{~d}$.

Daily or end-point samples were taken for the determination of inorganic nutrients, total and frac- 
tioned chl $a$, bacteria, pico- and nanophytoplankton, total organic carbon (TOC), total nitrogen (TN), total phosphorus (TP), particulate matter (carbon, nitrogen and phosphorus), microphytoplankton and epifluorescence microscopy (heterotrophic and autotrophic nanoflagellates). To test to what extent the effects of turbulence were the result of maintaining a large fraction of planktonic cells suspended in the water column, we thoroughly mixed the microcosms at the end of the experiments until the settled material was completely resuspended, and sampled again for some variables. This procedure should not be mistaken for a resuspension experiment.

Inorganic nutrients (nitrate, nitrite, ammonium, phosphate and silicate) were determined following the methods of Hansen \& Koroleff (1999) with minor modifications. We used an Alliance Evolution II autoanalyser and analysed 2 replicates per sample.

TOC and TN were determined with a Shimadzu TOC-VCSH analyser equipped with an additional Total Nitrogen Module as described in Nieto-Cid et al. (2005). Approximately $10 \mathrm{ml}$ of water were collected in pre-combusted $\left(450^{\circ} \mathrm{C}, 12 \mathrm{~h}\right)$ glass ampoules. $\mathrm{H}_{3} \mathrm{PO}_{4}$ was added to acidify the sample to $\mathrm{pH}<2$ and the ampoules were heat-sealed and stored in the dark at $4^{\circ} \mathrm{C}$ until analysis. The basic principle for the quantitation of TOC relies on the destruction of organic matter, either chemically or via heat at high temperatures. We used a catalyticallyaided platinum $680^{\circ} \mathrm{C}$ combustion technique. The system was standardised daily with a potassium hydrogen phthalate standard. The performance of the analyser was tested with DOM (dissolved organic matter) reference materials provided by Prof. D. Hansell (University of Miami). Detection limits for

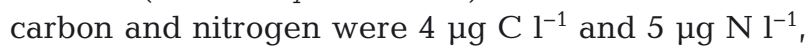
respectively.

TP was determined by wet oxidation and colorimetry (Hansen \& Koroleff 1999). Briefly, $25 \mathrm{ml}$ aliquots were mixed with $2 \mathrm{ml}$ of the oxidant reagent in glass vials and autoclaved at $121^{\circ} \mathrm{C}$ for $30 \mathrm{~min}$. Once the vials were cooled down to room temperature, $600 \mu \mathrm{l}$ of ascorbic acid were added and left to act for $2 \mathrm{~min}$. We finally added $600 \mu \mathrm{l}$ of the combined reagent and kept the samples in the dark for $15 \mathrm{~min}$. Readings were done at $880 \mathrm{~nm}$ with a CaryWin UV Spectrophotometer.

Particulate organic phosphorus (POP) was also measured by wet oxidation and colorimetry (Hansen \& Koroleff 1999), but additional steps were required to analyse the particulate fraction. First, 500 to $600 \mathrm{ml}$ samples were filtered through pre-combusted Whatman GF/F filters, and these filters were immersed in $25 \mathrm{ml}$ aliquots of milli-Q water. We added the oxidant reagent and autoclaved samples at $121^{\circ} \mathrm{C}$ for $30 \mathrm{~min}$. The oxidation process partially disintegrates the filter, so the vials were centrifuged at $7970 \times g$ for $10 \mathrm{~min}$ to separate the solid fragments. Once the supernatant was extracted, we carried out the colorimetric reaction as previously described.

Particulate carbon and nitrogen ( $\mathrm{PC}$ and $\mathrm{PN}$, respectively) were collected (up to $1000 \mathrm{ml}$ ) on precombusted Whatman GF/F filters. Measurements were carried out with a Perkin Elmer $2400 \mathrm{CHN}$ analyser. An acetanilide standard was used daily. The precision of the method is $\pm 0.3 \mu \mathrm{mol} \mathrm{C} \mathrm{l}^{-1}$ and $\pm 0.1 \mu \mathrm{mol} \mathrm{N} \mathrm{l^{-1 }}$. Samples were kept frozen at $-80^{\circ} \mathrm{C}$ until analysis.

Total chl $a$ and the fraction of chl a from phytoplankton $>10 \mu \mathrm{m}$ were measured by fluorometry, as described in Yentsch \& Menzel (1963). For total chl $a_{\text {, }}$ $20 \mathrm{ml}$ samples were filtered through Whatman GF/F glass fibre filters. For the $>10 \mu \mathrm{m}$ fraction, $50 \mathrm{ml} \mathrm{sam}$ ples were filtered through $10 \mu \mathrm{m}$ pore size Whatman Nuclepore polycarbonate filters. All filters were immersed in $90 \%$ acetone and left for $24 \mathrm{~h}$ in the dark at $4^{\circ} \mathrm{C}$. The fluorescence of the extract was measured with a Turner Designs fluorometer.

Bacteria were counted by flow cytometry (Gasol \& del Giorgio 2000). Samples (1.8 ml) were fixed with $0.18 \mathrm{ml}$ of a $10 \%$ paraformaldehyde and $0.5 \%$ glutaraldehyde mixture. Subsamples of $200 \mu \mathrm{l}$ were stained with SYTO13 (Molecular Probes) at $2.5 \mu \mathrm{mol}$ $\mathrm{l}^{-1}$ (diluted in DMS), left to stain for $15 \mathrm{~min}$ in the dark and then run at low speed (ca. $12 \mu \mathrm{min}^{-1}$ ) through a Becton Dickinson FACScalibur flow cytometer with a laser emitting at $488 \mathrm{~nm}$. We added $10 \mu \mathrm{l}$ per sample of a $10^{6} \mathrm{ml}^{-1}$ solution of yellow-green $0.92 \mu \mathrm{m}$ latex beads (Polysciences) as an internal standard.

Flow cytometry was also used to enumerate picoand nanophytoplankton. In this case, subsamples of $1 \mathrm{ml}$ were left unstained and were run at high speed (ca. $50 \mu \mathrm{l} \mathrm{min}{ }^{-1}$ ). Again, $10 \mu \mathrm{l}$ of a $10^{6} \mathrm{ml}^{-1}$ solution of beads was used as an internal standard. As a crosscontrol to determine cell abundances and to ensure stability of the flow, the flow speed was calibrated every 10 samples by measuring sample volume before and after a 10 min run.

Autotrophic (ANF) and heterotrophic nanoflagellates (HNF) were enumerated by epifluorescence microscopy (Porter \& Feig 1980). Samples were fixed with glutaraldehyde ( $1 \%$ final concentration), stained with DAPI $\left(5 \mu \mathrm{g} \mathrm{ml}^{-1}\right)$ and filtered on $0.8 \mu \mathrm{m}$ black polycarbonate membranes. The filters were mounted on microscope slides and kept frozen at $-20^{\circ} \mathrm{C}$. Counts were done on a Nikon Labophot epi- 
fluorescence microscope at $1250 \times$ magnification. We counted a minimum of 200 nanoflagellates on each filter, and sized them in 4 classes $(<4 \mu \mathrm{m}, 4-8 \mu \mathrm{m}$, 8-16 $\mu \mathrm{m}$ and $>16 \mu \mathrm{m})$ using a calibrated ocular micrometer. Autotrophic and heterotrophic organisms were distinguished by the red fluorescence of chlorophyll under blue light excitation.

Other phytoplankton cells (mainly diatoms, dinoflagellates and coccolithophores) were identified and counted in $50 \mathrm{~cm}^{3}$ settling chambers using the Utermöhl technique (Utermöhl 1958). Samples were fixed with a formalin-hexamine solution $(0.4 \%$ final concentration) and kept at $4^{\circ} \mathrm{C}$ until counting. The observed organisms were sized (length and width) and classified to the lowest possible taxonomic level.

To measure plankton biomass, chl a values were converted to carbon using a factor of $50 \mu \mathrm{g}$ of carbon per $\mu \mathrm{g}$ of chl a (this is within the range of values reported by Delgado et al. (1992) for surface waters in the NW Mediterranean). Bacterial biomass was estimated by flow cytometry following the methods described in Gasol \& del Giorgio (2000); we used a

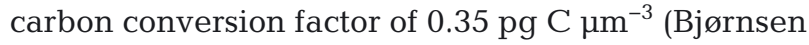
1986), which resulted in an average content of $21 \mathrm{fg}$ C cell ${ }^{-1}$. Cell volume $\left(\mu \mathrm{m}^{3}\right)$ of nanoflagellates was established from the mean value of each size class, assuming a prolate spheroid shape. In this latter case, conversion to carbon was calculated with the equation pg C cell ${ }^{-1}=0.433 \times$ cell volume ${ }^{0.863}$ (Verity et al. 1992).

\section{Statistical analyses}

To assess the effects of turbulence and the different nutrient amendments, we performed analyses of covariance (ANCOVA) and analyses of variance (ANOVA). In ANCOVA, the experimental sampling time was used as the continuous predictor, while turbulence and nutrient addition were categorical variables. Data for time $=0$ was excluded. Samples for ANF and HNF were only collected on Days 0 and 3; consequently, time could not be included as a covariate and we performed ANOVA tests. The Bonferroni post-hoc test was applied to identify differences among the various groups in each experiment. Biological data were log-transformed prior to statistical analyses. The level of significance was set to 0.05 . Statistical analyses were performed with Statistica version 6 (StatSoft) and JMP version 8 (SAS Institute Inc).

In order to test whether there were generalised trends in the response of phytoplankton growth with respect to nutrient concentration, we pooled the chl a growth rate data from both experiments and plotted them with respect to ammonium or nitrate concentration. Michaelis-Menten type curves were adjusted to the data using KaleidaGraph non-linear regression (KaleidaGraph v4.0, Synergy Software). Data were fitted to the equation $y=V_{\max } \times\left[x /\left(x+K_{\mathrm{m}}\right)\right]$, where $y$ is growth rate $\left(\mathrm{d}^{-1}\right), V_{\max }$ is the maximum uptake rate, $x$ is the substrate concentration, and $K_{\mathrm{m}}$ is the substrate concentration at which reaction time is half its maximal value. Affinity $\left(\alpha_{\max }\right)$ was calculated as the quotient of the maximum reaction rate $V_{\max }$ to the half-saturation constant $K_{\mathrm{m}}$.

\section{RESULTS}

\section{Initial conditions}

Expt 1: autumn experiment

The background scenario for autumn sampling was typical for cold months, featuring well-mixed, nutrient-rich waters and a great abundance of large autotrophic cells. Sampling took place right before the passing of a frontal system, during a short period with higher wind intensities and increased waves. Indeed, both wind speed and wave height reached local maxima - with regard to the weekly average conditions - about 1 or $2 \mathrm{~d}$ prior to our sampling. Air temperature ranged from 11.0 to $18.3^{\circ} \mathrm{C}$. Given the shallowness of our sampling station, increases in turbulence can easily lead to the mixing of the water column and induce a moderate increase in nutrients. Moreover, there was a regular daily breeze regime which may have further contributed to the mixing of the water masses and the nutrient injection.

Nutrient concentrations presented balanced stoichiometric ratios (N:P:Si were close to Redfield ratios) and most inorganic nitrogen was in the form of $\mathrm{NO}_{3}{ }^{-}$ rather than $\mathrm{NH}_{4}{ }^{+}$. Therefore, the situation was somewhat equivalent to that found in nutrient-rich systems in winter. The initial planktonic community was consistent with the winter-like situation: nearly $75 \%$ of the total carbon biomass corresponded to autotrophic organisms, and chl a concentration was $1.79 \pm 0.06 \mu \mathrm{g}$ $\mathrm{l}^{-1}$, a high value when compared to the average annual records for the sampling area. Approximately half of this chl a corresponded to phytoplankton larger than $10 \mu \mathrm{m}$. Looking further into the microphytoplanktonic species, we saw that diatoms were the most abundant group. In contrast, cyanobacteria were found in low numbers, and the concentration of bacte- 
ria did not differ significantly from annual average values $\left(\sim 1.1 \times 10^{6}\right.$ cells ml $^{-1}$; Romero 2010$)$.

Expt 2: spring experiment

A strong low-pressure system took place during the survey and although no rainfall was registered, strong easterly winds and intense swells affected the region. The physicochemical and biological characteristics of the water column were substantially different from those found in autumn. Except for ammonium, the concentration of inorganic nutrients was low and the N:P ratio largely exceeded Redfield values ( $\mathrm{N}: \mathrm{P} \approx 28$ ). The phytoplanktonic community was mostly composed of small cells (i.e. chl a from phytoplankton $>10 \mu \mathrm{m}$ represented only $20 \%$ of total chl a) and cell densities were low, both for autotrophic and heterotrophic organisms. Notably, the concentration of bacteria was ca. $4 \times 10^{5}$ cells ml $^{-1}$, a value well below the usual bacterial abundances in these coastal waters (Romero 2010).

\section{Nutrient uptake}

In autumn, rapid consumption of phosphate and ammonium took place in both the controls and the enriched experimental treatments, whereas nitrate and silicate decreased toward the end of the experiment, and decreased more in turbulent than in still containers (Fig. 2a). Note that the relative consumption of N, P and Si approximately matched Redfield proportions. In spring, the consumption of nutrients was progressive, and abrupt changes were not observed in any of the treatments (results were very consistent between replicates, Fig. 2b). Unlike in the autumn experiment, decreases in N, P and Si did not match Redfield proportions. When only silicate and phosphate were added (Am tanks), a larger fraction of them was consumed than in the controls, yet a consistent decrease of available inorganic nitrogen was not observed. When the additions comprised silicate, phosphate and nitrate (Nit tanks), the uptake of phosphate and silicate was nearly the same, but the concentration of ammonium and nitrate decreased. Adding higher amounts of silicate and phosphate but ensuring a maximum final concentration of $4 \mu \mathrm{mol} \mathrm{l}^{-1}$ $\mathrm{N}$ did not alter the situation: the more phosphate and silicate were available, the more these nutrients were consumed, although the concomitant uptake of inorganic nitrogen was very low, and some nitrogen was even released (Am2, Nit2 treatments).

\section{Biological response}

Despite different initial conditions in biological and chemical parameters, some common trends in the response of the organisms could be observed in both experiments.

Phytoplankton

Autotrophic organisms had a generally positive response in all experimental treatments. In still, unenriched tanks, the concentration of chl a remained constant and the relative fraction of chl a from phytoplankton $>10 \mu \mathrm{m}$ declined (Fig. 3). When turbulence was applied, however, both the total chl a and the $>10 \mu \mathrm{m}$ fraction increased in autumn (larger organisms representing ca. $70 \%$ of the total pigment concentration) while with regard to still tanks minor differences occurred in spring. With nutrient additions, regardless of the total load or the $\mathrm{N}$ partitioning, chl a increased swiftly and the effect was significantly larger under turbulence (Fig. 3, Table 2). The amendments favoured the growth of large pigmented cells: in autumn, the fraction of chl a from phytoplankton $>10 \mu \mathrm{m}$ verged on $50 \%$ in still tanks and increased to nearly $90 \%$ under turbulence; in spring, the $>10 \mu \mathrm{m}$ fraction fluctuated around $30 \%$ in still tanks and reached ca. $50 \%$ under turbulent conditions. Differences in chl a concentration between still and turbulent enriched tanks remained significant when accounting for the material settled in the containers.

Final chl a concentrations in spring were low compared to the chl a values obtained during the autumn experiment. The total build-up of biomass in spring was constrained by the low initial abundance of organisms, so we compared actual differences between experiments by adjusting an exponential growth model to the daily values of $\mathrm{chl} a$ and $\mathrm{chl} a$ from phytoplankton $>10 \mu \mathrm{m}$. Net growth rates, i.e. the growth rate of each treatment minus the value of the controls, were consistently higher in autumn than in spring, though differences were significant for total chl a $(\mathrm{p}<0.001)$, but not for the $>10 \mu \mathrm{m}$ fraction $(p \approx 0.10)$. At the same time, there was a generalised increase in chl a under turbulence and nutrient amendment conditions somewhat independent of the nature of the treatment (Fig. 4).

$\mathrm{Chl}$ a measurements integrated a number of organisms which may have had differential response patterns depending on the treatment. Unravelling the dynamics of the different groups is thus key for explaining divergences in the biological outcome 
a
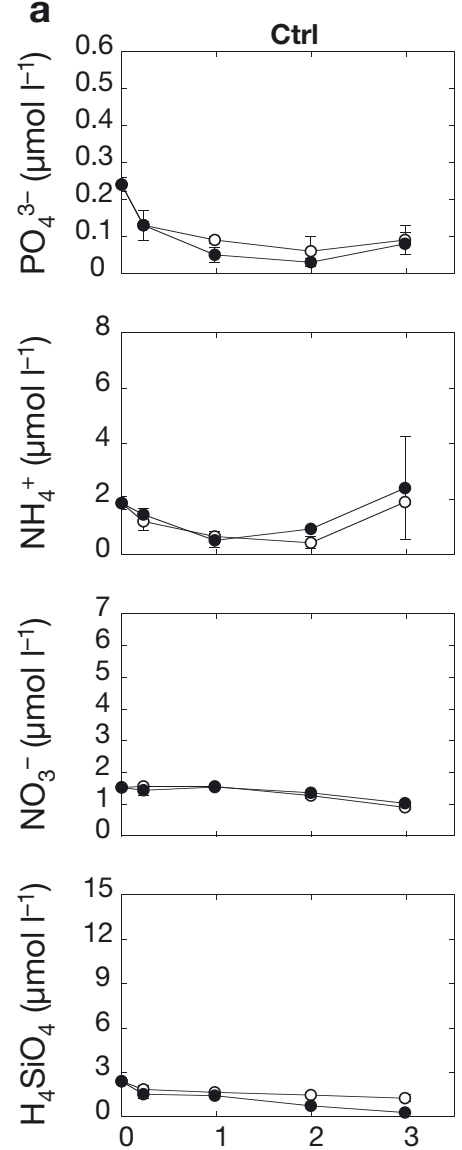

b
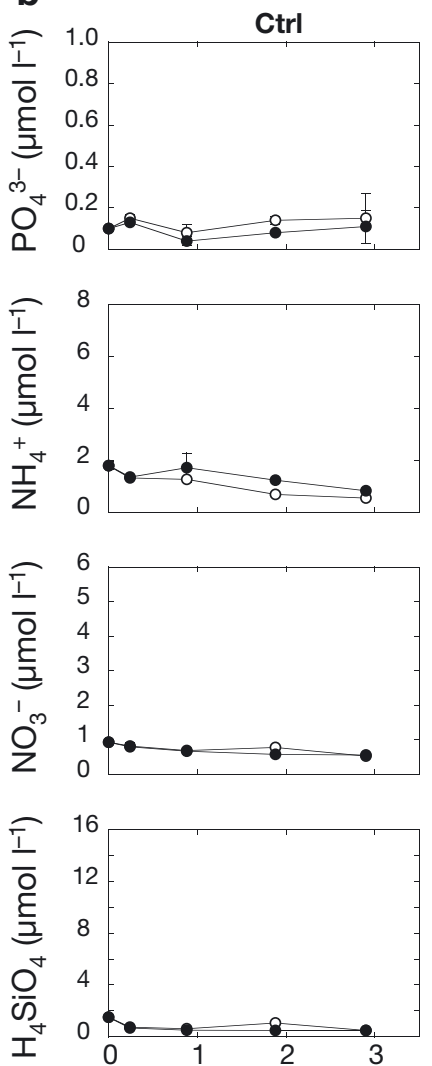
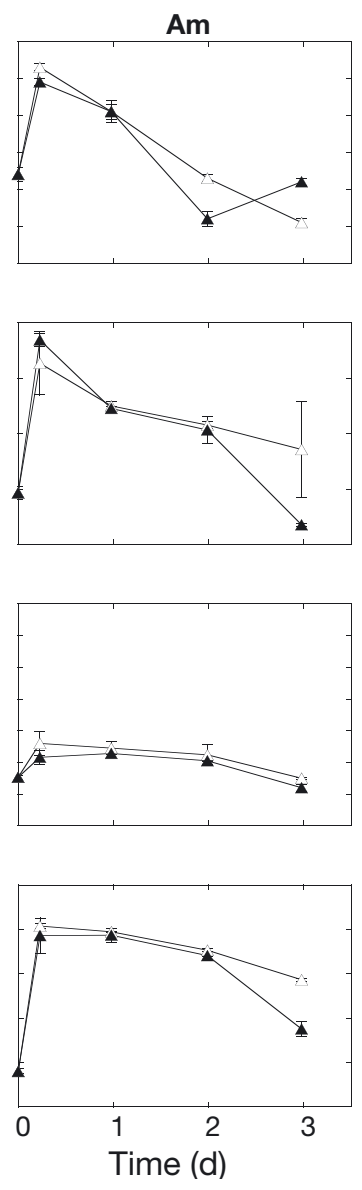

Am
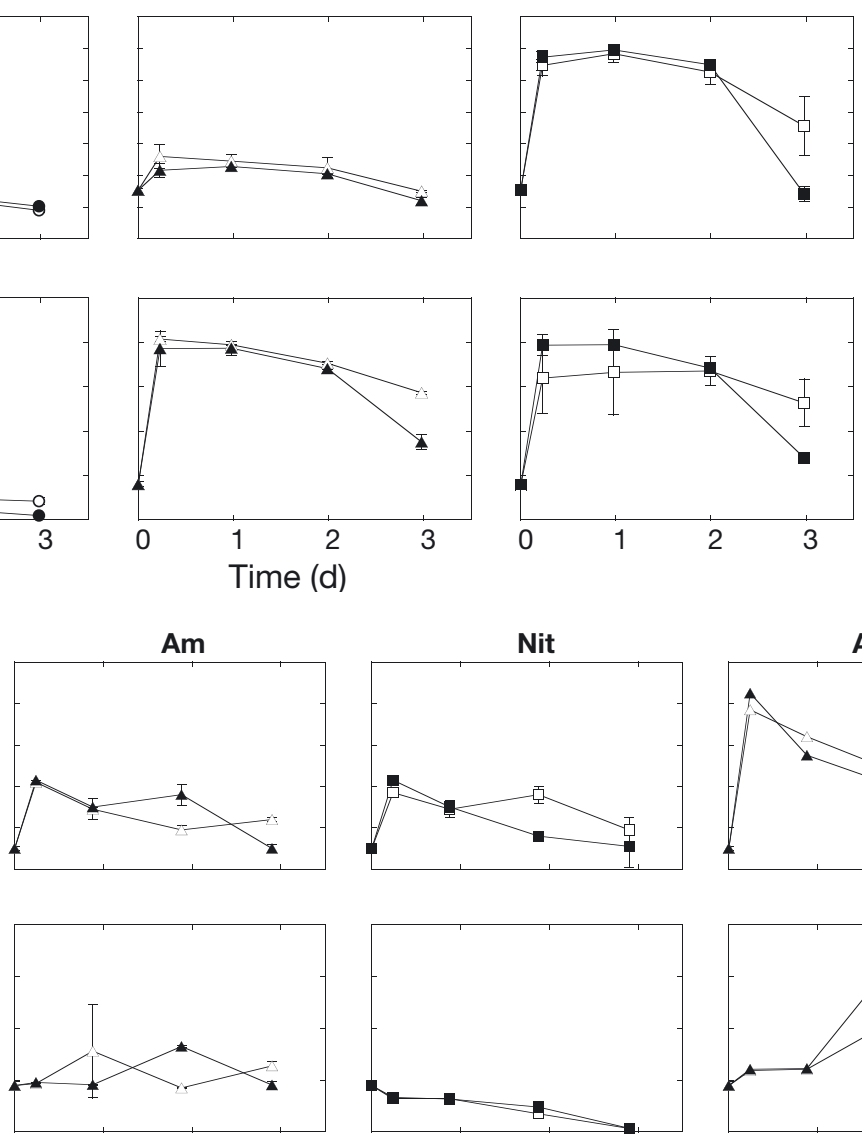

Fig. 2. Nutrient concentrations in the (a) autumn and (b) spring experiments. Open symbols represent still conditions and solid symbols represent turbulent conditions. Codes for nutrient treatments as described in Table 1. Error bars in Ctrl, Am and Nit represent the SD of 2 replicate tanks; some error bars are obscured by the symbol
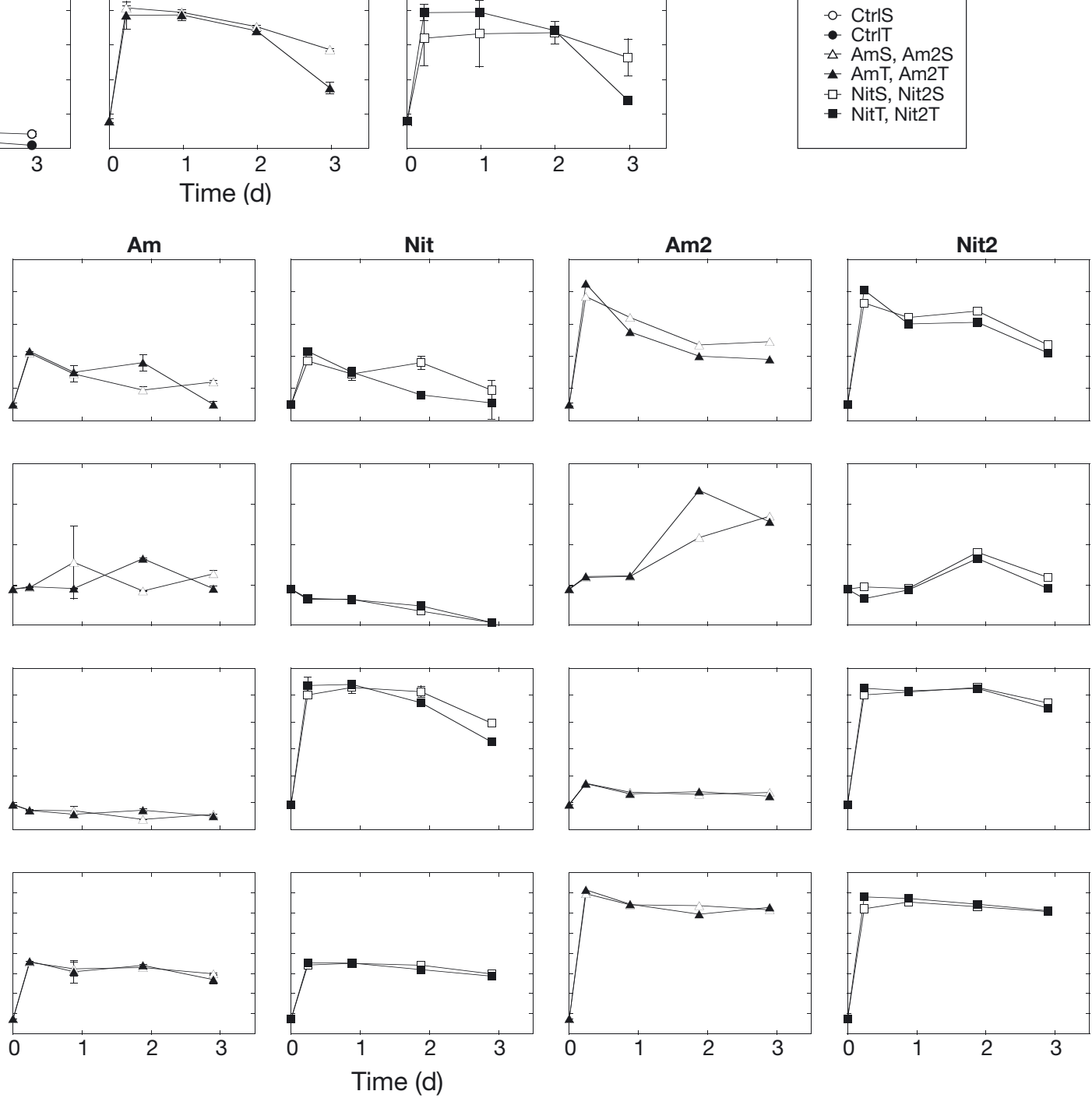
Table 2. Statistical results (ANOVA and ANCOVA) for both experiments. Treatments are all categorical except time (h), which is the experimental sampling time and is used as a covariate in the analysis. Time $=0$ was excluded. Turbulence is treated as an on-off variable, and nutrient categories are described in Table 1. A-/HNF: auto/heterotrophic nanoflagellates; TOC/-P/-N: total organic carbon/phosphorus/nitrogen; PC/-N/-OP: particulate carbon/nitrogen/organic phosphorus. Note that only a few parameters in Expt 2 were available for the 5 nutrient categories, while the rest have been measured in Ctrl, Am and Nit tanks. Degrees of freedom (df) and p-values (p) are shown $^{*}{ }^{*} \mathrm{p}<0.05,{ }^{* *} \mathrm{p}<0.01,{ }^{* * *} \mathrm{p}<0.001 . \mathrm{C}_{\mathrm{bact}} / \mathrm{C}_{\text {osmotr }}$ : ratio of bacterial $\mathrm{C}$ biomass to total osmotrophic biomass (i.e. the addition of chl $a$ and bacteria in units of $\mu \mathrm{g} \mathrm{C}^{-1}$ )

\begin{tabular}{|c|c|c|c|c|c|c|c|c|c|c|c|c|}
\hline \multirow[t]{2}{*}{ Parameter } & \multirow[t]{2}{*}{$\mathrm{n}$} & \multirow[t]{2}{*}{$\mathrm{R}^{2}$} & \multicolumn{2}{|c|}{ Intercept } & \multicolumn{2}{|c|}{ Time $(\mathrm{h})$} & \multicolumn{2}{|c|}{ Nutrients } & \multicolumn{2}{|c|}{ Turbulence } & \multicolumn{2}{|c|}{$\begin{array}{c}\text { Nutrients } \times \\
\text { Turbulence }\end{array}$} \\
\hline & & & $\mathrm{df}$ & $\mathrm{p}$ & $\mathrm{df}$ & $\mathrm{p}$ & df & $\mathrm{p}$ & df & $\mathrm{p}$ & df & $\mathrm{p}$ \\
\hline \multicolumn{13}{|l|}{ Expt 1 (autumn) } \\
\hline Chl a $\left(\mu g \mathrm{l}^{-1}\right)$ & 36 & 0.635 & 1 & 0.408 & 1 & $* * *$ & 2 & $* * *$ & 1 & $* * *$ & 2 & 0.144 \\
\hline Chl $a>10 \mu \mathrm{m}\left(\mu \mathrm{g} \mathrm{l}^{-1}\right)$ & 36 & 0.574 & 1 & 0.154 & 1 & $* * *$ & 2 & $* *$ & 1 & $* * *$ & 2 & 0.170 \\
\hline Chl $a>10 \mu \mathrm{m} / \mathrm{chl} a$ & 36 & 0.705 & 1 & $* * *$ & 1 & $* * *$ & 2 & $* *$ & 1 & $* * *$ & 2 & * \\
\hline Synechococcus sp. (cells ml $\mathrm{ml}^{-1}$ ) & 36 & 0.956 & 1 & $* * *$ & 1 & $* * *$ & 2 & 0.138 & 1 & 0.484 & 2 & 0.212 \\
\hline Picoeukaryotes (cells ml ${ }^{-1}$ ) & 36 & 0.392 & 1 & $* * *$ & 1 & $*$ & 2 & $* * *$ & 1 & 0.588 & 2 & 0.138 \\
\hline Bacteria (cells ml ${ }^{-1}$ ) & 36 & 0.868 & 1 & $* * *$ & 1 & $* * *$ & 2 & ${ }^{*}$ & 1 & $* * *$ & 2 & 0.684 \\
\hline ANF (cells ml ${ }^{-1}$ ) & 12 & 0.973 & 1 & $* * *$ & - & - & 2 & $* * *$ & 1 & 0.218 & 2 & 0.236 \\
\hline HNF (cells ml ${ }^{-1}$ ) & 12 & 0.881 & 1 & $* * *$ & - & - & 2 & $* * *$ & 1 & 0.777 & 2 & 0.092 \\
\hline TOC $\left(\mu \mathrm{mol} \mathrm{l} 1^{-1}\right)$ & 36 & 0.279 & 1 & $* * *$ & 1 & $*$ & 2 & $*$ & 1 & * & 2 & 0.708 \\
\hline $\mathrm{TN}\left(\mu \mathrm{mol} \mathrm{l} \mathrm{l}^{-1}\right)$ & 36 & 0.445 & 1 & $* * *$ & 1 & $* *$ & 2 & $* * *$ & 1 & 0.841 & 2 & 0.820 \\
\hline $\mathrm{TP}\left(\mu \mathrm{mol} \mathrm{l}^{-1}\right)$ & 36 & 0.926 & 1 & $* * *$ & 1 & $* * *$ & 2 & $* * *$ & 1 & * & 2 & 0.650 \\
\hline $\mathrm{PC}\left(\mu \mathrm{mol} \mathrm{l} \mathrm{l}^{-1}\right)$ & 36 & 0.611 & 1 & $*$ & 1 & $* * *$ & 2 & $* *$ & 1 & $* * *$ & 2 & 0.357 \\
\hline $\mathrm{PN}\left(\mu \mathrm{mol} \mathrm{l}^{-1}\right)$ & 36 & 0.648 & 1 & $* *$ & 1 & $* * *$ & 2 & $* * *$ & 1 & $* * *$ & 2 & 0.156 \\
\hline $\mathrm{C}_{\text {bact }} / \mathrm{C}_{\text {osmotr }}$ & 36 & 0.856 & 1 & $* * *$ & 1 & $* * *$ & 2 & $* * *$ & 1 & $* *$ & 2 & 0.823 \\
\hline Total biomass $\left(\mu g \mathrm{C}^{-1}\right)$ & 12 & 0.959 & 1 & $* * *$ & - & - & 2 & $* * *$ & 1 & $* * *$ & 2 & $* *$ \\
\hline Autotrophic biomass & 12 & 0.949 & 1 & $* * *$ & - & - & 2 & $* * *$ & 1 & $* * *$ & 2 & 0.566 \\
\hline \multicolumn{13}{|l|}{ Expt 2 (spring) } \\
\hline Chl a $\left(\mu \mathrm{gl}^{-1}\right)$ & 48 & 0.697 & 1 & 0.483 & 1 & $* * *$ & 4 & $* * *$ & 1 & ${ }^{* *}$ & 4 & 0.726 \\
\hline Chl $a>10 \mu \mathrm{m}\left(\mu \mathrm{g} \mathrm{l} \mathrm{l}^{-1}\right)$ & 48 & 0.526 & 1 & 0.189 & 1 & *** & 4 & ${ }^{*}$ & 1 & ** & 4 & 0.659 \\
\hline Chl $a>10 \mu \mathrm{m} / \mathrm{chl} a$ & 48 & 0.236 & 1 & $* * *$ & 1 & 0.104 & 4 & ** & 1 & 0.083 & 4 & 0.914 \\
\hline Synechococcus sp. (cells ml $\mathrm{ml}^{-1}$ ) & 48 & 0.308 & 1 & $* * *$ & 1 & * & 4 & 0.070 & 1 & ${ }^{* *}$ & 4 & 0.459 \\
\hline Picoeukaryotes (cells ml ${ }^{-1}$ ) & 48 & 0.790 & 1 & $* * *$ & 1 & $* * *$ & 4 & $* * *$ & 1 & 0.708 & 4 & 0.818 \\
\hline Bacteria (cells ml ${ }^{-1}$ ) & 48 & 0.224 & 1 & $* * *$ & 1 & $*$ & 4 & 0.086 & 1 & $*$ & 4 & 0.902 \\
\hline ANF (cells ml-1) & 12 & 0.960 & 1 & $* * *$ & - & - & 2 & $* * *$ & 1 & 0.141 & 2 & * \\
\hline HNF (cells ml-1) & 12 & 0.164 & 1 & $* * *$ & - & - & 2 & 0.145 & 1 & 0.699 & 2 & 0.496 \\
\hline $\mathrm{TP}\left(\mu \mathrm{mol} \mathrm{l} \mathrm{l}^{-1}\right)$ & 36 & 0.680 & 1 & $* * *$ & 1 & $* *$ & 2 & $* * *$ & 1 & 0.112 & 2 & 0.168 \\
\hline PC $\left(\mu \mathrm{mol} \mathrm{l} \mathrm{l}^{-1}\right)$ & 36 & 0.220 & 1 & $* * *$ & 1 & 0.111 & 2 & 0.259 & 1 & * & 2 & 0.248 \\
\hline PN $\left(\mu \mathrm{mol} \mathrm{l} \mathrm{l}^{-1}\right)$ & 36 & 0.436 & 1 & $* * *$ & 1 & $* *$ & 2 & $* *$ & 1 & $* *$ & 2 & 0.334 \\
\hline POP $\left(\mu \mathrm{mol} \mathrm{l}{ }^{-1}\right)$ & 12 & 0.976 & 1 & $* * *$ & - & - & 2 & $* * *$ & 1 & ** & 2 & 0.082 \\
\hline $\mathrm{C}_{\text {bact }} / \mathrm{C}_{\text {osmotr }}$ & 48 & 0.648 & 1 & $* * *$ & 1 & $* * *$ & 4 & ${ }^{*}$ & 1 & 0.468 & 4 & 0.707 \\
\hline Total biomass $\left(\mu g \mathrm{C}^{-1}\right)$ & 12 & 0.987 & 1 & $* * *$ & - & - & 2 & $* * *$ & 1 & $* * *$ & 2 & $* * *$ \\
\hline Autotrophic biomass & 12 & 0.927 & 1 & $* * *$ & - & - & 2 & $* * *$ & 1 & 0.079 & 2 & 0.065 \\
\hline
\end{tabular}

of experimental simulations. The smallest autotrophic components, cyanobacteria, showed dynamics largely detached from either the enrichments or turbulence. In autumn, Synechococcus sp. and Prochlorococcus sp. cells presented synchronous peaks in all tanks $24 \mathrm{~h}$ after the start of the experiment, but their abundances decayed to values below the initial concentrations by Day 3 (Fig. 3a). In spring, Synechococcus sp. increased during the first $48 \mathrm{~h}$ (in some cases, up to $72 \mathrm{~h}$ ), again with minor differences among experimental enrichments. Turbulence had significant effects on the concentration of cyanobacteria during the spring experiment (Table 2).
In contrast, nutrient inputs had major effects on the abundance of pico- and nanoeukaryotes, and stimulated the growth of phototrophic nanoflagellates. Small eukaryotes increased in both experiments following nutrient additions, and their maxima always occurred after the cyanobacterial peak, either on Day 2 or 3 of the experiments. In autumn, no growth differences were found between the still and turbulent 'Am' tanks, i.e. maximum concentration values were similar, while in 'Nit' containers, turbulence significantly boosted the growth of picoeukaryotes compared to still conditions (Bonferroni post-hoc test, $\alpha<$ 0.05 , NitT-NitS were split into different groups). In 


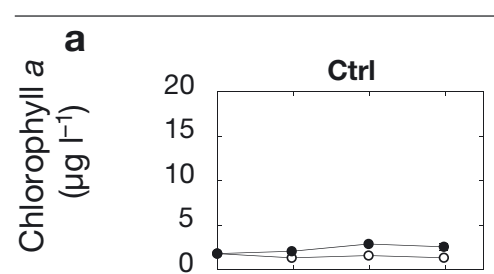

咅

읏

등

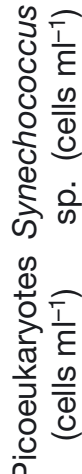
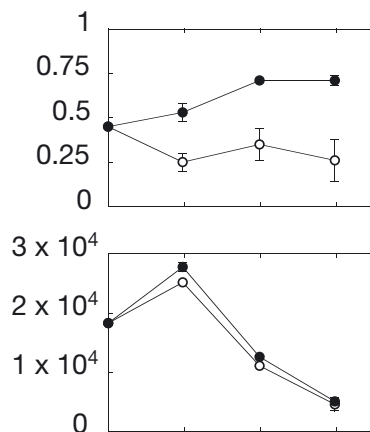

$\frac{1}{E}$
$\frac{0}{\bar{D}}$
$\frac{0}{0}$
$\frac{1}{\bar{D}}$
$\frac{0}{0}$

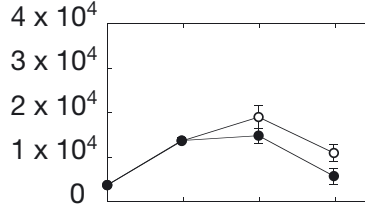

$4 \times 10^{6}$

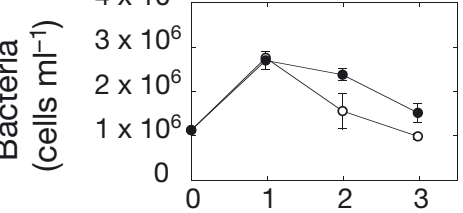

b
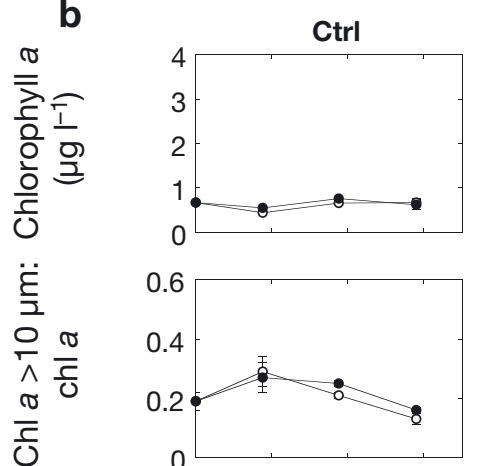

ô

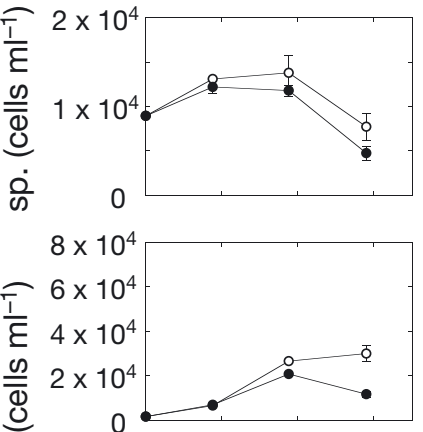

는 $5 \times 10^{6}$

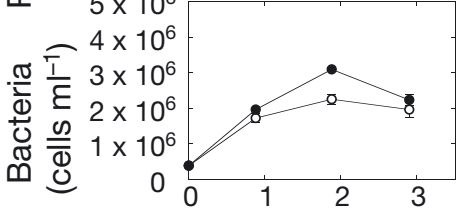

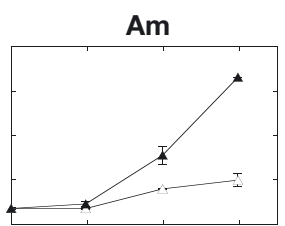
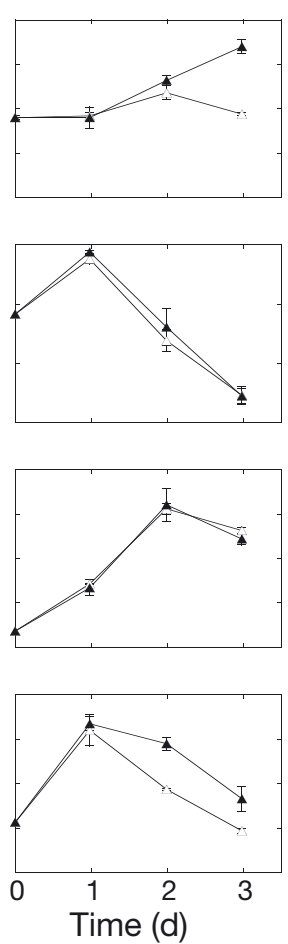

Am
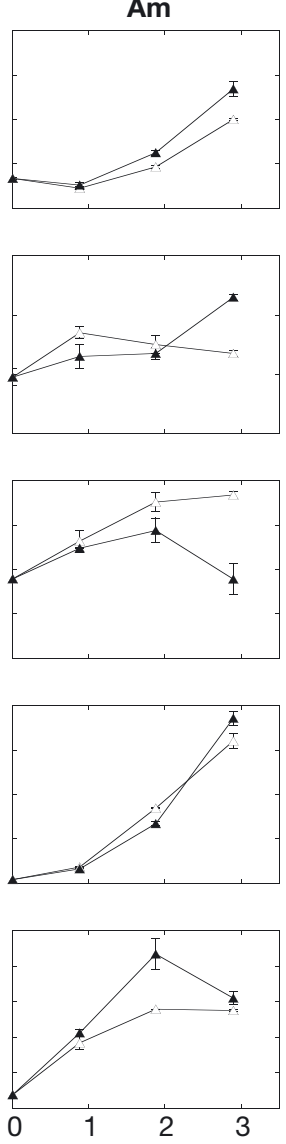
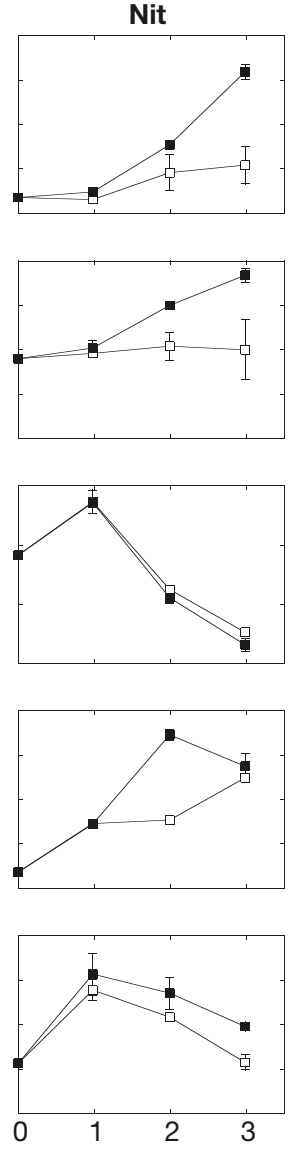

Nit
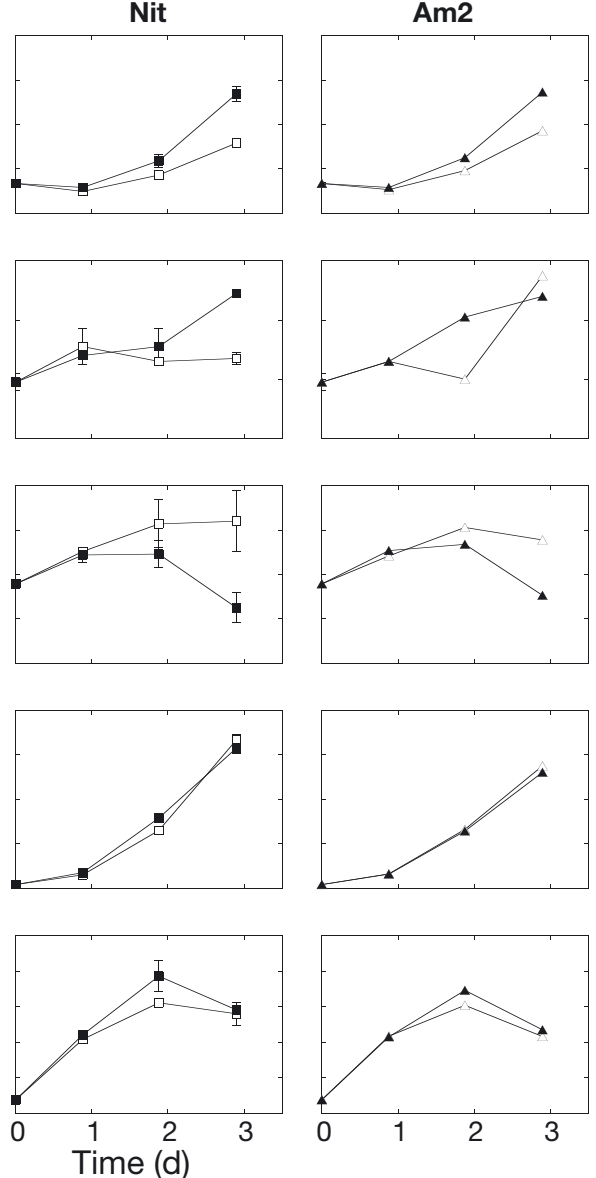

Fig. 3. Concentrations of several planktonic organisms during the (a) autumn experiment and (b) spring experiments. Top to bottom: chl $a_{\text {, }}$ ratio of chl a from phytoplankton $>10 \mu \mathrm{m}$ to total chl a, Synechococcus sp., picoeukaryotes and heterotrophic bacteria. Prochlorococcus sp. and nanoeukaryotes matched the dynamics of Synechococcus sp. and picoeukaryotes respectively, but they were far less abundant and have not been included in the plots. Open symbols represent still conditions and solid symbols represent turbulent conditions. Codes for nutrient treatments as described in Table 1. Error bars in Ctrl, Am and Nit represent the SD of 2 replicate tanks; some error bars are obscured by the symbol

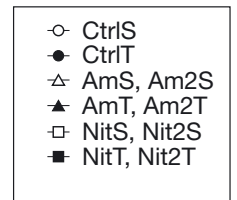

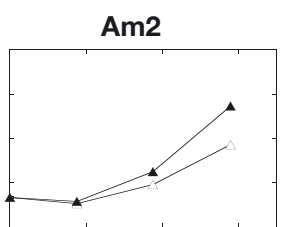
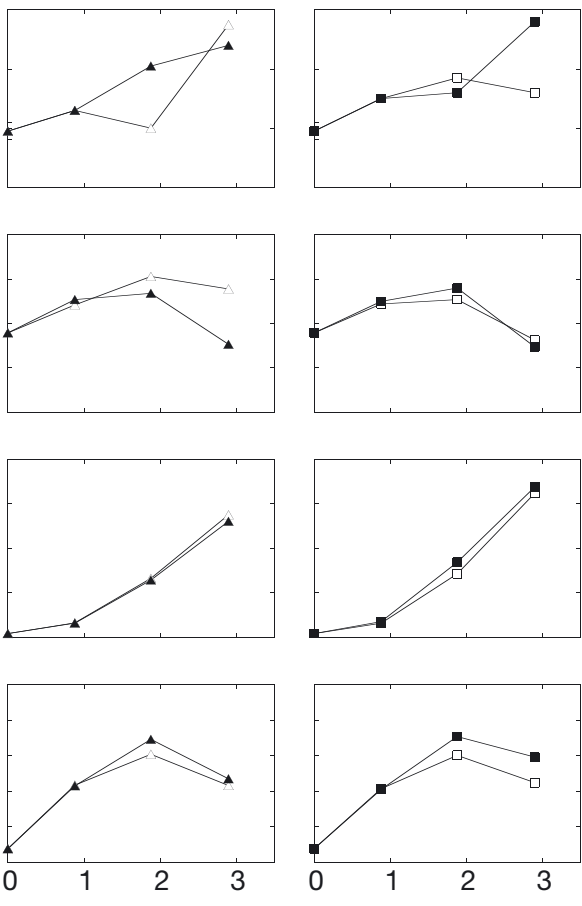

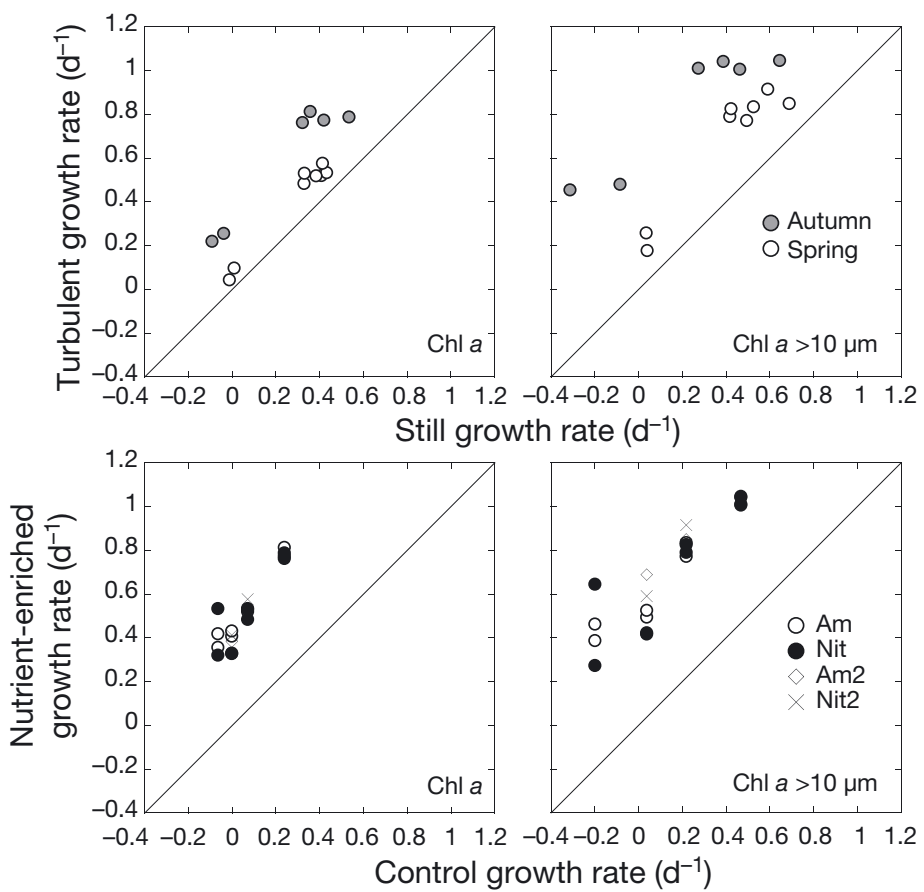

Fig. 4. Growth rates $\left(\mathrm{d}^{-1}\right)$ of total $\mathrm{chl} a$ and chl a from phytoplankton $>10 \mu \mathrm{m}$ in turbulent vs. still conditions (top), and enriched vs. control tanks (bottom). Data from autumn and spring experiments are plotted together. The diagonal line corresponds to 1:1

spring, picoeukaryotes increased in concentration by more than 1 order of magnitude in the 'Ctrl' tanks (from $1.6 \times 10^{3}$ to $>2 \times 10^{4}$ cells $\mathrm{ml}^{-1}$ ), but nutrient enrichments encouraged further growth, and final concentrations were ca. 40-fold the initial values $\left(\sim 6 \times 10^{4}\right.$ cells ml ${ }^{-1}$, Fig. 3b). Such exponential growth occurred in all enriched tanks, regardless of turbulence or specific amendments (differences among enriched treatments were statistically non-significant, Bonferroni post-hoc test).

The highest variations among treatments were found in pigmented nanoflagellates (Fig. 5). Differences were particularly clear during the autumn simulation: in the controls, the abundance of pigmented nanoflagellates increased ca. 5- to 6-fold within $3 \mathrm{~d}$, and minor differences were observed between the still and turbulent tanks. The response was similar in Nit treatments (even additions of nitrate and ammonium), yet the variability among tanks was larger. When the nutrient inputs were enriched in ammonium (Am tanks), final nanoflagellate cell concentrations were close to $1.5 \times 10^{4} \mathrm{cells} \mathrm{ml}^{-1}$, about 1 order of magnitude larger than the initial values. Large increases in the concentration of pigmented nanoflagellates were also detected during the spring experiment, both in the controls (6- to 8-fold higher than initial values) and in enriched tanks, where final con- centrations of plastidic nanoflagellates ranged between $3.1 \times 10^{4}$ and $4.6 \times 10^{4}$ cells $\mathrm{ml}^{-1}$. Nanoflagellates seemed to grow significantly better in Nit than in Am treatments, particularly when turbulence was applied (Table 2, Bonferroni post-hoc test: NitT > NitS, AmS, AmT > CtrlS, CtrlT).

Along with nanoflagellates, diatoms were the other phytoplanktonic group most stimulated by the enrichments (Fig. 6), turbulence being a critical factor. In autumn, under still conditions, only the Nit tank showed an increase in the initial number of diatoms, while under turbulence, both amended tanks (Am, Nit) reached high diatom concentrations. Unlike nanoflagellates, diatoms seemed to be most favoured in Nit treatments; differences were, however, statistically non-significant, likely due to the limited number of samples. A large part of this growth corresponded to small Chaetoceros spp. cells (data not shown). In spring, results showed a varying balance of diatoms and dinoflagellates as a function of both turbulence and nutrient amendments (Fig. 6). Initially, dinoflagellates and diatoms were equally

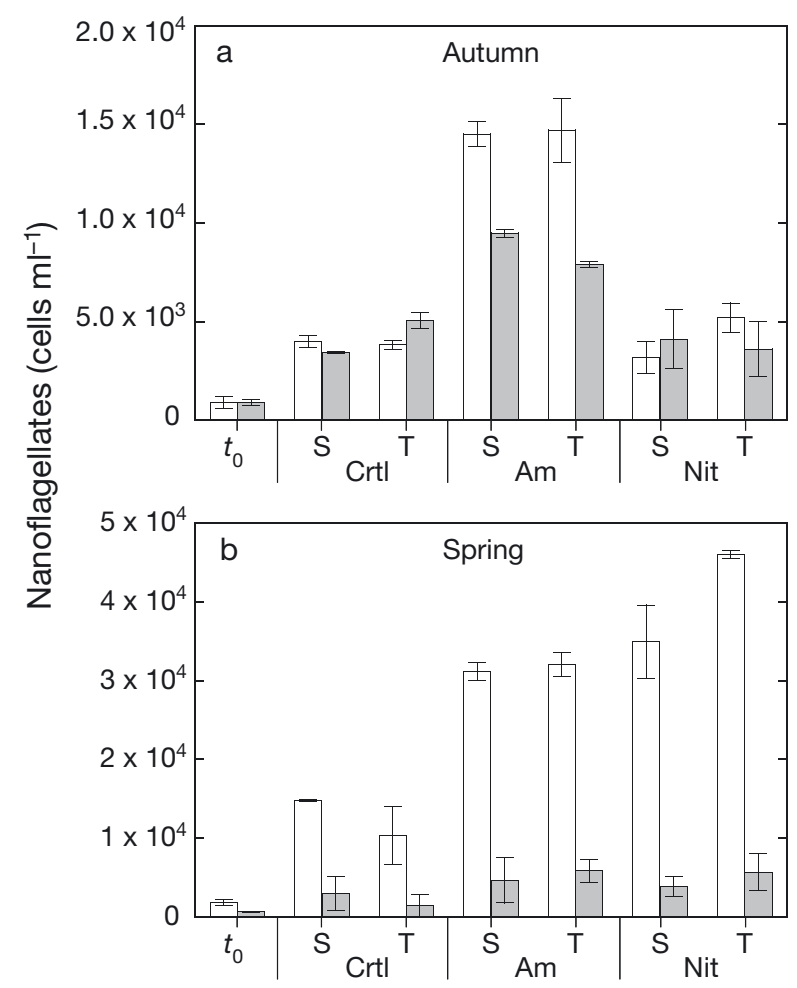

Fig. 5. Concentration of pigmented (open bars) and non-pigmented nanoflagellates (grey bars) at the beginning and at the end of the (a) autumn and (b) spring experiments. Initial values were common for all treatments. Data are average \pm $\mathrm{SD}$ of 2 replicate tanks. Note the different ordinate scales between experiments. Codes for nutrient treatments as described in Table 1 


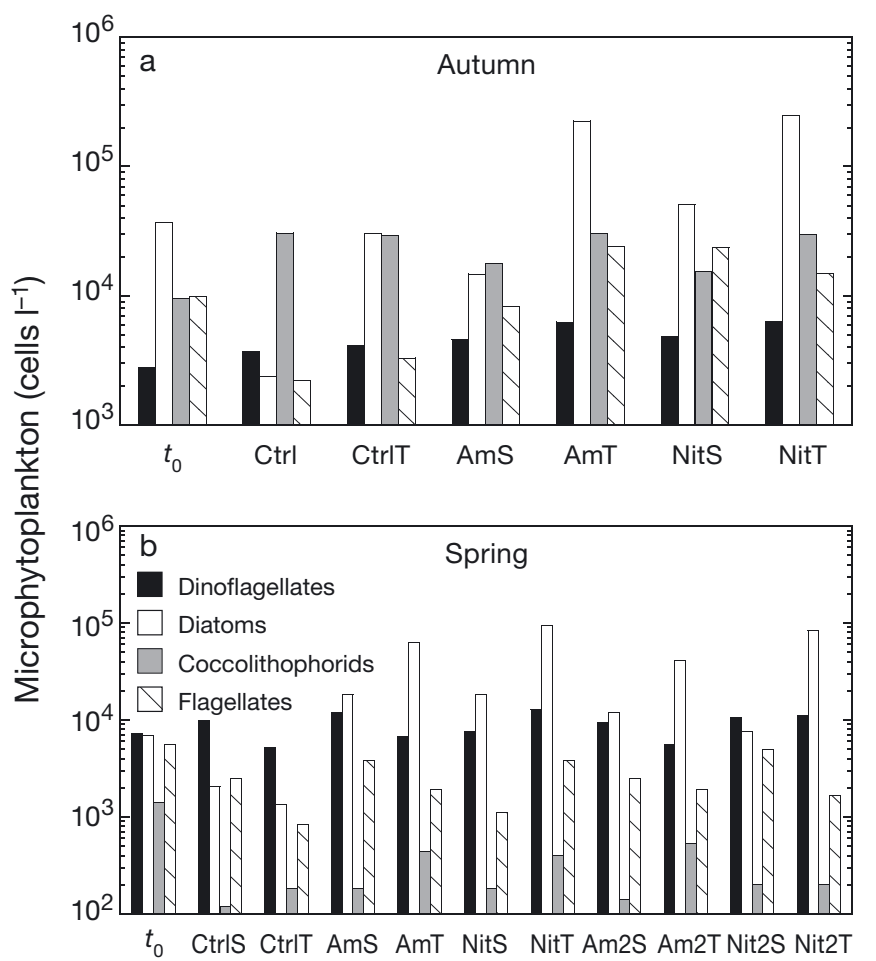

Fig. 6. Abundance of several groups of microphytoplankton at the beginning and end of the (a) autumn and (b) spring experiments. Initial values were common for all treatments. Codes for nutrient treatments as described in Table 1

abundant, though cell concentrations were low for

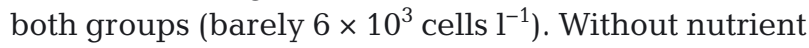
additions, dinoflagellates maintained their populations, but diatoms decayed to minimum levels; in tanks receiving additional nutrients, diatoms outgrew dinoflagellates. Turbulent treatments clearly favoured the proliferation of diatoms $(p<0.05)$.

When the chl a growth rate data from both experiments were pooled (Fig. 7), Michaelis-Menten type equations showed that under still water conditions, the affinity $\left(\alpha_{\max }\right)$ for either form of nitrogen was approximately equal. Under turbulence, the affinity increased, more so for nitrate than for ammonium, and particularly for the fraction of chl a from phytoplankton $>10 \mu \mathrm{m}$.

\section{Heterotrophic organisms}

Bacteria peaked within 24-48h (Fig. 3), irrespective of nutrient enrichments, in both experiments. Cell concentrations were systematically higher in enriched than in non-enriched tanks, and in turbulent than in still conditions, although some of these differences were not statistically significant $(p \approx 0.08$ for nutrient forcing in spring, Table 2).
A generally positive effect was also observed for heterotrophic flagellates in both autumn and spring simulations. In autumn, heterotrophic flagellates increased in all treatments, but were particularly abundant in ammonium-rich tanks (AmS, AmT). Indeed, final numbers in Am treatments were twice the final concentrations of heterotrophic nanoflagellates in Ctrl and Nit tanks $\left(8 \times 10^{3}\right.$ vs. $4 \times 10^{3}$ cells ml $^{-1}$ respectively, Fig. 5). In spring, the growth of HNF was increased in enriched conditions compared to control tanks, but moderate differences were observed at the end of the experiment between Am and Nit treatments.

Autotrophic carbon was initially very abundant in autumn $(\sim 74 \%)$ and continued to dominate after $3 \mathrm{~d}$ (Fig. 8). While this percentage remained nearly constant in the controls, all enriched conditions had final autotrophic carbon fractions between 80 and $90 \%$. The combined effect of nutrient addition and turbulence was also visible in terms of total biomass. Biomass values remained below $200 \mu \mathrm{g} \mathrm{Cl}^{-1}$ in the con-

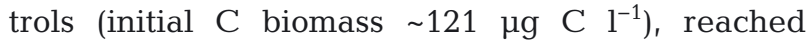
ca. $300 \mu \mathrm{C} \mathrm{Cl}^{-1}$ in still, enriched tanks and increased to ca. $900 \mu \mathrm{g} \mathrm{Cl}^{-1}$ in enriched, turbulent containers. Significant biomass differences between still and turbulent treatments persisted after accounting for the material settled on the bottom of all amended tanks (data not shown). In comparison, in the spring experiment, autotrophs represented $63 \%$ of initial C biomass. In the controls, autotrophs comprised less than $40 \%$ of total C biomass at the end of the experiment; in enriched tanks this proportion was slightly higher, but always remained below the initial values (Fig. 8). The final biomass measurements showed the sparse initial community and the somewhat lower biological growth observed in the spring experiment. Differences between enriched and non-enriched treatments were clear $(p<0.001$, Table 2$)$, but maximum biomass values were lower than those obtained in autumn (220 vs. $\left.904 \mu \mathrm{g} \mathrm{C} \mathrm{l}^{-1}\right)$. Again, there was no distinction in total biomass between $\mathrm{Am}$ and Nit treatments, yet turbulence seemed to have a positive effect on $\mathrm{C}$ biomass when combined with nutrient addition $(\mathrm{p}<0.001$, Table 2$)$.

\section{DISCUSSION}

One of the purposes of our experimental setup was to drive the system away from the environmental conditions at the time of sampling, simulating forcing events. The ultimate goal was not to compare the absolute variation of biological variables, but to 

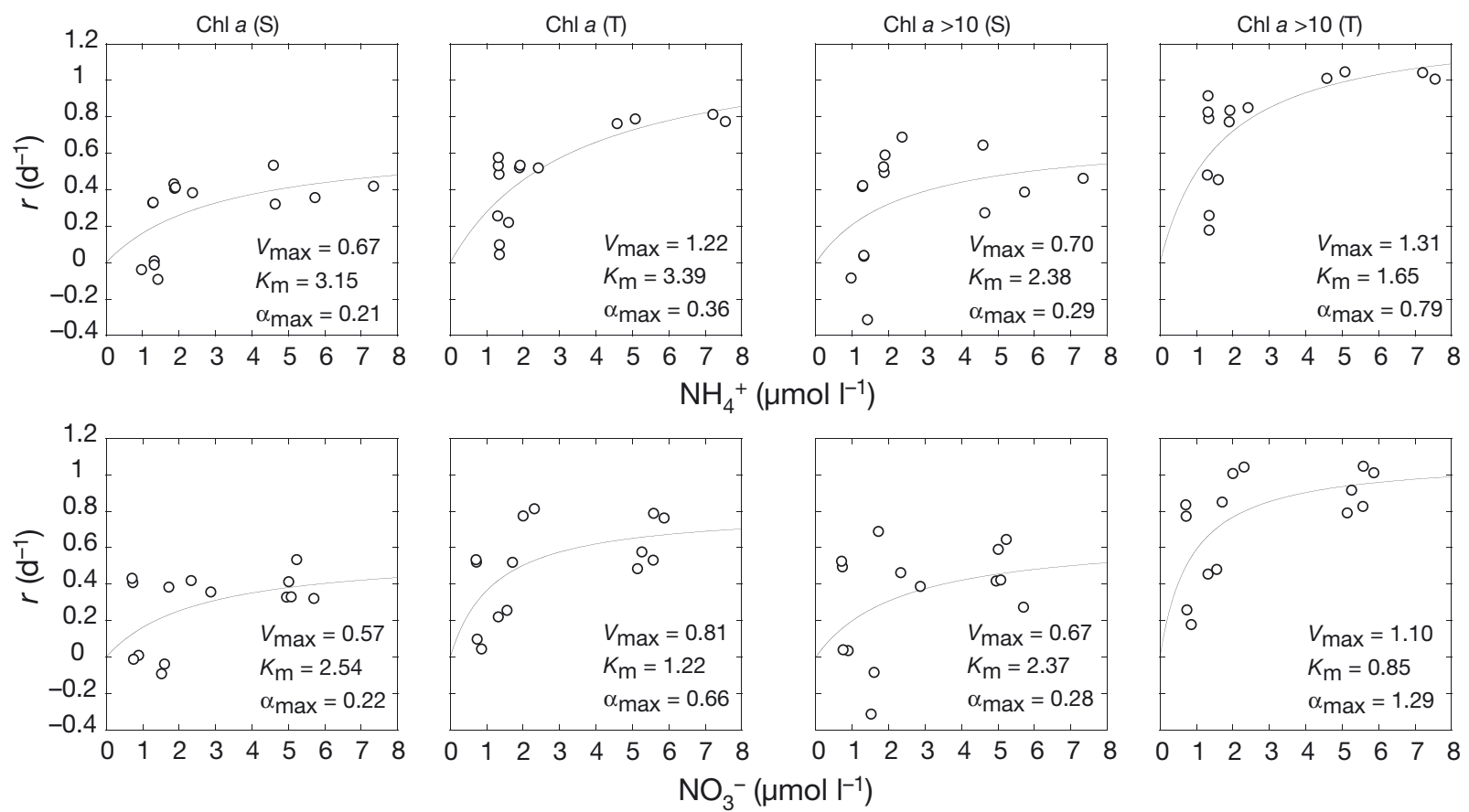

Fig. 7. Growth rates $\left(r, \mathrm{~d}^{-1}\right)$ of $\mathrm{chl} a$ and chl a from phytoplankton $>10 \mu \mathrm{m}$ vs. the concentration of ammonium (top) and nitrate (bottom) measured in the tanks after the initial amendments. Data from the autumn and spring experiments are pooled. S: still treatments; T: turbulent treatments. We fitted Michaelis-Menten kinetics to the data $\left(y=V_{\max } \times\left[x /\left(x+K_{\mathrm{m}}\right)\right]\right)$; the corresponding values of $K_{\mathrm{m}}, V_{\max }$ and $\alpha_{\max }$ are given in the panels. y: growth rate; $V_{\max }$ : maximum uptake rate; $x$ : substrate concentration; $K_{\mathrm{M}}$ : half-saturation constant

explore the potential of episodic enrichments to induce shifts within the community. Thus, we sacrificed some treatment level homogeneity between experiments and adapted the nutrient additions to the conditions found at the beginning of each experiment.

As a whole, the effects of the interplay between turbulence and $\mathrm{N}$ partitioning were clearer in the autumn simulation. In November the planktonic community was dominated by large autotrophs, mostly diatoms, and nutrient concentrations were high. Indeed, sampling water came from a well-mixed water column (temperature and salinity were homogeneous in the vertical CTD profile, data not shown) and this may have caused the input of nutrients from deeper waters and a concomiant burst of diatoms. Given the availability of nutrients in the initial water, we would expect organisms to grow not only in the enriched tanks,
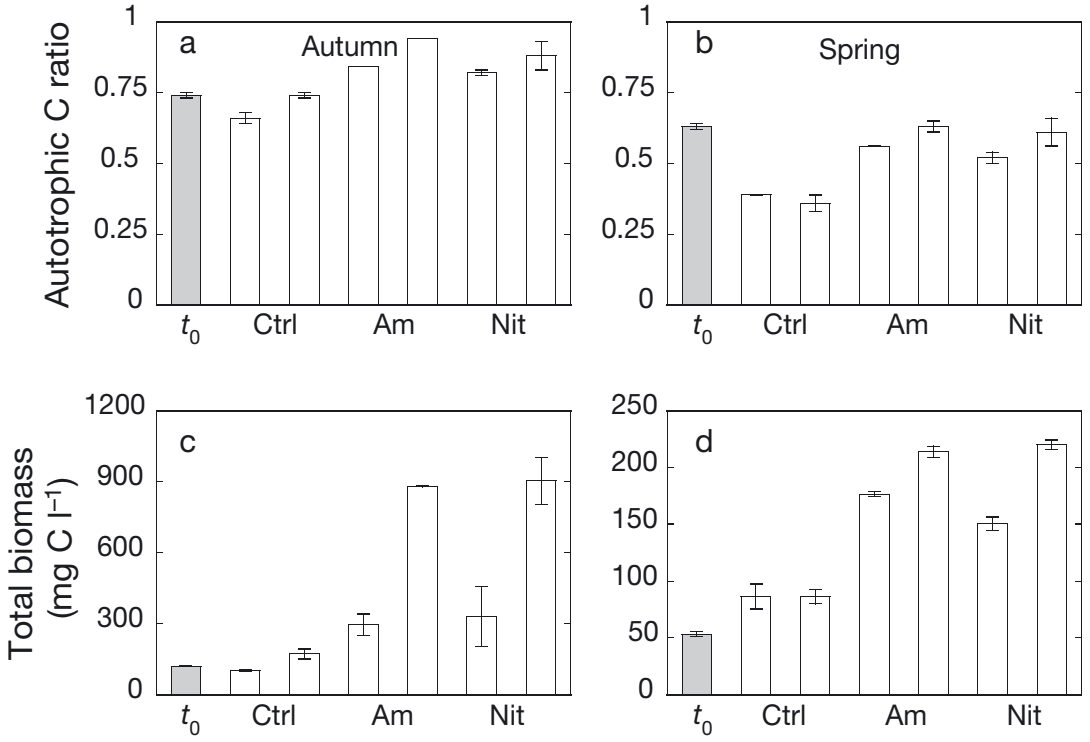

Fig. 8. $(\mathrm{a}, \mathrm{b})$ Ratio of autotrophic $\mathrm{C}$ biomass to total $\mathrm{C}$ biomass and $(\mathrm{c}, \mathrm{d})$ total biomass per experimental condition at the beginning and end of the $(a, c)$ autumn and (b,d) spring experiments. Initial values (shaded bars) were common for all treatments. Total biomass was calculated by adding the biomass of algae (derived from chl a), bacteria and heterotrophic flagellates. Autotrophic biomass corresponds to the conversion of chl a. Data are average \pm SD of 2 replicate tanks. Codes for nutrient treatments as described in Table 1 
but also in the controls. However, there were no net chl a increases in still control tanks (CtrlS), while a moderate increase in chl a occurred in turbulent controls (CtrlT). It seemed that the net outcome was due to the loss of large diatoms and an increase of small phototrophs. Small autotrophic cells (cyanobacteria, picoeukaryotes, plastidic nanoflagellates) reached similar abundances in still and turbulent tanks, but large diatoms were mostly favoured under turbulence. As a result, turbulent tanks sustained greater concentrations of chl $a$, with a particularly large fraction of chl a from phytoplankton $>10 \mu \mathrm{m}$. Estrada et al. (1987) reported that a diatom bloom after enclosure is a predictable occurrence at times of the year when the inoculum community contains detectable nutrients. In our experiment, diatom growth did happen, but there was a fast decay of the populations due to sedimentation that was partly counteracted under turbulence. In the context of shallow coastal areas with low freshwater influence and moderate, occasional nutrient inputs, such as the one in our study, sinking of cells may be an important disadvantage for large organisms, giving hydrodynamics a preponderant role in maintaining the structure of the community.

In April, a low concentration of nutrients and a low abundance of planktonic organisms (mainly small cells) characterised the community. According to the time-series for the study area (Romero 2010), the spring sampling took place only a few weeks after the decay of the annual chlorophyll maximum, suggesting that the scarcity of nutrients and the sparse planktonic population could correspond to a postbloom state. In particular, all nutrients except for ammonium were in low concentrations. Ammonium is a by-product of bacterial metabolism and nutrient recycling, and thus suggests the presence of a welltuned microbial community. In spring, chl a concentrations remained close to the initial values in unenriched tanks, and no differences were found between still and turbulent treatments. This is consistent with the fact that most of the autotrophs were dinoflagellates and small nanoflagellates, and both groups are little affected by sedimentation processes. Indeed, some centric diatoms decayed, but an increase in autotrophic nanoflagellates offset the loss.

\section{Effect of nutrient amendments and N-source}

The growth of organisms was maximal in enriched experimental conditions in both autumn and spring simulations. In autumn, Nit amendments were equally distributed between nitrate and ammonium. In practice, that meant an increase in nutrient concentration similar to the one which had naturally occurred at sea following wind-wave mixing (the ratio of ammonium to nitrate was ca. 1 in the initial seawater). In Am treatments, the ammonium:nitrate ratio was 9:1, mimicking the $\mathrm{N}$ partitioning of sewage waters. Nitrate uptake has been related to the predominance of large phytoplankton, whereas ammonium has been shown to preferentially favour bacteria and small autotrophs (Le Bouteiller 1986, Wheeler \& Kirchman 1986, Stolte et al. 1994, Riegman \& Noordeloos 1998, Riegman et al. 1998, Mercado et al. 2008), so we expected to see a shift in the community composition.

Most groups of small cells (i.e. picoeukaryotes, cyanobacteria, heterotrophic bacteria) showed similar responses in all amended treatments, irrespective of $\mathrm{N}$ partitioning, and minor differences were also observed in bulk chl a values. A likely explanation is that there were enough nutrients for all organisms to grow, regardless of their preferences for nitrate or ammonium, so that the organisms could maintain their preferential uptake for $3 \mathrm{~d}$ without triggering any mechanism of competitive exclusion. Similarly, Estrada et al. (2003) explored changes in the phytoplankton following nutrient additions with variable $\mathrm{N}: \mathrm{P}$ ratios. Although they did not focus on differences in the source of nitrogen and there are some clear divergences between their experimental setup and our own (e.g. single initial amendment vs. continuous intermittent nutrient supply, temporal length of the experiment, total nutrient load), the results of Estrada et al. (2003) support the view that nutrient imbalances per se are not important when the absolute amounts of each nutrient exceed limitation (or preference) thresholds. In their experiments, differences in the phytoplanktonic cells were only perceptible during a post-bloom phase, ca. $15 \mathrm{~d}$ after the first nutrient enrichment. We restricted the length of the experiment to a maximum of $3 \mathrm{~d}$ because (1) it is a likely duration for episodic forcing events in this part of the coast (Guadayol \& Peters 2006) and (2) we were interested in community shifts directly related to varying nutrient inputs, and not in those mediated through secondary trophic interactions. Divergences in post-bloom communities may be caused by multiple factors which are outside the scope of the present study.

Nonetheless, pigmented nanoflagellates did have a distinct response between enrichments during the autumn simulation: abundances were significantly higher in ammonium-rich tanks (Fig. 5). The increase 
of nanoflagellates was consistent between replicate tanks and matched the smaller increases of diatoms in Am than in Nit treatments. These results thus support the premise that small autotrophs grow preferentially on ammonium, whereas nitrate favours diatoms and other large phytoplankton cells. Le Bouteiller (1986) reported similar affinities for ammonium and nitrate in several size fractionation experiments, and Riegman et al. (1998) showed a good correspondence between the abundance of small autotrophs and the consumption of ammonium, and preferential uptake of nitrate by large phytoplankton during bloom events. Note that in our simulation, Am tanks displayed excess ammonium but Nit tanks had an even proportion of ammonium and nitrate. This could explain the overwhelming response of nanoflagellates in Am tanks and the comparatively moderate reaction of diatoms in Nit tanks, in spite of their potential advantage in nitrate uptake over other groups.

Various hypotheses have been put forward to explain the different affinities for $\mathrm{N}$ compounds between phytoplanktonic groups. Under the tenet that ammonium is the preferred $\mathrm{N}$ source for all algae, Morel et al. (1991) suggested that growth affinity of small cells for ammonium is better than that of large cells, because large organisms suffer from stronger diffusion limitation. Large phytoplankton would therefore be more dependent on alternative nitrogen sources, and nitrate is often available in the highest concentrations. Stolte et al. (1994) remarked, however, that this differential advantage of small cells would only be relevant under diffusionlimited conditions, whereas under fluctuating nutrient regimes large algae would dominate the community on account of their storage capacity. More specifically, they argued that ammonium, being a positively charged or neutral $\left(\mathrm{NH}_{3}\right)$ molecule, may not be a suitable storage product because it can easily diffuse through biological membranes. In contrast, nitrate is a negatively charged ion that cannot diffuse as easily through the cell membrane. Hence, nitrate can be stored in higher concentrations than ammonium, possibly in the cell vacuole. This may explain, to some extent, the relationship between cell size and ammonium and nitrate uptake characteristics (Stolte et al. 1994).

The results of the spring experiment were consistent with the trends observed in autumn. In spring, ammonium exceeded nitrate in the initial waters and the ratio of $\mathrm{N}$ to $\mathrm{P}$ was clearly unbalanced (indicating potential $\mathrm{P}$ limitation). We added phosphate and silicate in excess to overcome this potential P or Si limitation, then added variable amounts of $\mathrm{N}$, never surpassing a total concentration of

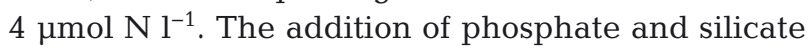
(Am treatments) induced some diatom growth, particularly under turbulence, but major immediate increases were observed in pigmented nanoflagellates and picoeukaryotes. Given that the initial water was enriched in ammonium, the observed growth of nanoflagellates and picoeukaryotes is in accordance with the autumn results, again underlining the affinity of small autotrophs for ammonium (Le Bouteiller 1986, Kokkinakis \& Wheeler 1988, Stolte et al. 1994). Interestingly, in Am treatments, the decrease of inorganic nitrogen was lower than that calculated from the phosphate drop, assuming Redfield ratios. This suggests luxury consumption of $\mathrm{P}$, which would agree with the seemingly P-limited condition of the cells in the inoculum (Thingstad et al. 1993, 2005, Ediger et al. 2005). Otherwise, the apparent lower $\mathrm{N}$ consumption could be due to grazing and rapid regeneration of $\mathrm{N}$ compounds (Dortch 1990). Rapid recycling processes would indeed be expected under oligotrophic conditions and from microbial communities dominated by small organisms subject to protistan grazing; that is, similar to our initial community. Recycling of $\mathrm{N}$ compounds could also explain the slight fluctuations of ammonium concentration observed in Am treatments.

When phosphate, silicate and nitrate were added (Nit treatments), the response of pico- and nanophytoplankton was very similar to Am treatments in terms of population dynamics and maximum abundances, but a slightly larger amount of diatoms was obtained in turbulent treatments (reflected also in the fraction of chl a from phytoplankton $>10 \mu \mathrm{m})$. Curiously, the net chl a increase and bacterial growth were similar in Am and Nit treatments, but whereas the consumption of nitrogen was slow in Am tanks, both ammonium and nitrate were rapidly depleted in Nit containers (Fig. 2). We argue that this discrepancy may be a consequence of community shifts and increased competition between organisms. In Am treatments, the abundance of ammonium favoured the growth of small autotrophs and bacteria, reinforcing the microbial loop and the regeneration of $\mathrm{N}$. In contrast, when the nutrient addition included nitrate, larger phytoplankton were further stimulated (mainly diatoms but also pigmented nanoflagellates), and these may be responsible for the greater uptake of $\mathrm{N}$ compounds, especially nitrate.

The pattern was repeated somewhat in the remaining treatments: in Nit2 tanks, we again added a combination of phosphate, silicate and nitrate, but the 
load of phosphate and silicate was 2-fold that in Nit treatments (see Table 1). This relative excess of $\mathrm{P}$ and $\mathrm{Si}$ with regard to $\mathrm{N}$ did not affect the growth of the organisms much, i.e. the peaks of cyanobacteria, picoeukaryotes, heterotrophic bacteria and microphytoplankton were similar in Nit and Nit2 tanks, yet again, the relative uptake of phosphate was larger than that of nitrate and silicate (assuming Redfield ratios). This suggests that cells performed some luxury $\mathrm{P}$ consumption if $\mathrm{N}: \mathrm{P}$ was low enough. In Am2 tanks, the total addition of $\mathrm{P}, \mathrm{Si}$ and $\mathrm{N}$ was as in Nit2 treatments, but we split nitrogen inputs into nitrate and ammonium. The results were very similar to those in Nit2 treatments except that the growth of microphytoplankton was clearly favoured at higher nitrate concentrations, as reported in the autumn experiment.

\section{Effect of turbulence}

In addition to the divergences found in dominant planktonic groups as a result of different N sources, enriched tanks in both experiments showed significant differences in the biomass of large phytoplankton cells between still and turbulent treatments, which persisted after accounting for the settled material (ANOVA, p $<0.05$ for chl $a$, chl $a>10 \mu \mathrm{m}$ and total $\mathrm{C}$ biomass). Indeed, there seemed to be an overlying size dependent gradient in the effects of turbulence on phytoplanktonic organisms, particularly in the autumn simulation. No changes in the abundance of cyanobacteria occurred under turbulence, but slight differences were seen for picoeukaryotes and nanoflagellates, and large increases were distinguishable in microphytoplanktonic cells, particularly in the number of diatoms. This differential influence is in agreement with the general theory concerning the effects of small-scale turbulence on planktonic individuals, and can be ascribed to a double process: (1) turbulence may prevent large cells from sinking and allows for sustained growth, as observed in unenriched enclosures; and (2) turbulence improves nutrient uptake in osmotrophic organisms, proportional to cell size (Lazier \& Mann 1989, Karp-Boss et al. 1996). The observed size-dependent effects of turbulence are fully coincident with the results in Cózar \& Echevarría (2005). A number of other studies (Petersen et al. 1998, Arin et al. 2002) also found that turbulence favours the abundance of large autotrophs under nutrient-rich conditions.

Turbulence also favoured an increase in bacterial abundance regardless of nutrient addition in both experiments ( $p<0.001$, Table 2$)$. We know from previous studies that bacteria show insignificant sedimentation, thus the positive response to turbulence may be due to either increased availability of large dissolved molecules and colloids, or shifts in the grazing pressure of phagotrophic flagellates (Peters et al. 1998, 2002, Malits et al. 2004).

In summary, in accordance with our initial hypothesis, the combination of nitrate and turbulence was particularly beneficial for diatoms in the 2 experiments. Based only on theoretical considerations, the flux of nitrate to cell surfaces should be slightly higher than ammonium under turbulent conditions. The nitrate molecule is heavier than the ammonium molecule, and has a lower molecular diffusivity. This results in a higher Sherwood number for nitrate under the same turbulent shear intensity. The difference is small, but may add to the preference for nitrate in large osmotrophs such as diatoms.

\section{Common patterns and general considerations}

Several common patterns can be drawn from the results of both experiments: (1) regardless of differences in absolute cell abundances, the biological succession always started with a peak of bacteria and cyanobacteria (24 h), a maximum in picoeukaryotes (48 to $72 \mathrm{~h}$ ) and finally an increase of nanoflagellates and microphytoplankton. (2) Although we used varying ratios of ammonium and nitrate, the results of both experiments hint at a preference of microphytoplankton (particularly diatoms) towards nitrate, and an advantage of small cells (particularly autotrophic nanoflagellates) under ammonium-rich conditions. However, the differential advantage of any of these groups owing to $\mathrm{N}$ partitioning could be substantially modified by turbulence. Thus, under ammonium-rich and turbulent conditions, the higher affinity of small cells for ammonium was partly counteracted by the positive effect of turbulence on the growth of large osmotrophs; conversely, if nitrate inputs were accompanied by mixing, the abundance of diatoms was largely favoured.

The interaction between $\mathrm{N}$ source and turbulence was clearly shown when plotting net chl a growth rates vs. substrate concentrations and fitting Michaelis-Menten kinetics. Although growth was enhanced under turbulence, settling dynamics in still and turbulent tanks may have biased the calculation of growth rates. Contrary to common belief, turbulence increases settling velocity of negatively buoyant cells (Ruiz et al. 2004), although this effect should 
be insignificant at the turbulence intensities used in this study. Further, this velocity increase may not happen in a finite container with a solid bottom boundary that cuts off downward velocities. In any case, turbulent treatments sustained a larger fraction of large cells within the water column, but we did observe more settled material in turbulent containers. Therefore, the relative importance of turbulence on nutrient affinity may be slightly biased, but the overall trends shown in Fig. 7 should hold.

A quick bacterial response was also found by Guadayol et al. (2009) in a series of experiments, but in their study, bacterial increases were rapidly overridden by autotrophic growth during most of the year. Estrada et al. (2003) also found bacterial peaks following nutrient additions; yet again, these were minor compared to the chl a response. Unlike these studies, water for our experiments was sampled in Barcelona's coastal waters. Near the city, the large anthropogenic influence likely causes high loads of dissolved organic substances. The availability of DOM stimulates bacterial production, and can dampen the degree of coupling between bacterial and primary productivity (Ducklow \& Kirchman 1983, Kirchman et al. 1989) or bias the equilibrium between bacteria and phytoplankton when both groups compete for limited resources. That could explain why bacterial peaks were large and systematically preceded phytoplankton growth in our experiments, despite the dissimilar initial communities and the differences in nutrient availability.

The higher growth rates of chl a found in autumn contrast with the conclusions of Guadayol et al. (2009), who analysed the response of autotrophs to nutrient enrichments during an annual cycle and found the largest biological changes in summer, and a modest response in winter. The authors speculated that the starvation state of the cells accounted for their differential behaviour. Briefly, long-lasting stratification during the warm period limited the inflow of nutrients, so the organisms were severely nutrient-limited and showed an enhanced response to experimental nutrient enrichments. In winter, the availability of nutrients already allowed high growth rates in natural waters, so that the addition of extra nutrients caused a relatively small response. These authors reported a wide range of chlorophyll growth rates in the spring, which could barely be discerned from rates obtained for other periods of the year. We deliberately selected 2 periods with rapid environmental transitions to avoid large differences in growth rates. Besides, direct comparisons cannot be fully established with Guadayol et al. (2009), since they assessed regular perturbations (nutrient amendments were low and constant throughout the year), whilst we shifted the load and the elemental ratio of our enrichments to test differential responses. Our perturbations were purposely in the upper range, thus the outcome may be substantially different.

One of our most striking results was the small divergence between enrichments in either the general community dynamics or the total growth in biomass. Sudden nutrient pulses certainly induced major changes within the planktonic community with respect to non-enriched scenarios, but whether these nutrient inputs were rich in nitrate or ammonium, or unbalanced in terms of elemental ratios (i.e. N:P:Si ratios clearly biased from Redfield values) did not seem to determine the immediate response of several groups, particularly the smallest components of the planktonic community. Indeed, one of our objectives was to examine whether abrupt community changes could be caused by quick nutrient flushes. It seems that in our system, shifts related to ammonium overload occurred more easily than those induced by excess nitrate; that is, the progress from diatom-dominated communities to assemblages dominated by pico- and nanoplankton was faster than the opposite shift, i.e. the switch from small cells to large osmotrophs after nitrate pulses. This limitation is partly due to the naturally slower response of large osmotrophs (e.g. Guadayol et al. 2009), and partly due to the presence of a very active background microbial loop, and was overcome under turbulent conditions. In any case, we are only considering the changes that happened within $3 \mathrm{~d}$. Longer delays can entail strong community shifts, but these may not reflect the direct effects of nutrient pulses on the community, particularly in coastal areas subjected to dynamic physical forcing and/or rapid water movements where nutrient spills can easily dissipate. Further, turbulence was a key determining factor for bulk community variables such as chl a concentration or total biomass, particularly when the community contained large autotrophic organisms.

In general, it seems that coastal assemblages frequently dominated by small cells, with tight predation checks and an active microbial loop, efficiently consume and recycle nutrient pulses and have potential to cushion the effects of episodic spills. Even during periods when these communities display larger fractions of diatoms and other microphytoplankton, inputs enriched in ammonium favour the rapid emergence of small autotrophs and heterotrophic bacteria, reinforcing the microbial loop and ultimately restricting the growth of large phytoplankton. On the 
other hand, the relative success of diatoms is strongly influenced by the availability of nitrate, but also by the turbulence regime: diatom growth may be fostered in coastal waters receiving high ammonium loads and featuring a dynamic microbial loop if nutrient inputs are coupled with turbulent mixing. Finally, community shifts linked to nutrient imbalances may not always be measurable in terms of chl a or total biomass, but changes in the size distribution and function of the community may be significant.

Acknowledgements. We thank Ò. Guadayol, A. Sabata, E. Laguillo and C. Romera-Castillo for their valuable help during the experiments. We are also grateful to V. Pérez for her technical assistance with chemical analyses. Microphytoplankton was counted and sized by M. Delgado. E.R. was supported by the Departament d'Educació i Universitats de la Generalitat de Catalunya and the European Social Fund. F.P. was a Ramón y Cajal scientist. This study was funded by the Spanish projects VARITEC (CTM2004-04442-C02), PIE CSIC (200830I101), STORM (CTM2009-09352) and ADEPT (CTM2011-23458).

\section{LITERATURE CITED}

Allen JI, Siddorn JR, Blackford JC, Gilbert FJ (2004) Turbulence as a control on the microbial loop in a temperate seasonally stratified marine systems model. J Sea Res 52: $1-20$

Arin L, Marrasé C, Maar M, Peters F, Sala MM, Alcaraz M (2002) Combined effects of nutrients and small-scale turbulence in a microcosm experiment. I. Dynamics and size distribution of osmotrophic plankton. Aquat Microb Ecol 29:51-61

Baretta JW, Ebenhöh W, Ruardij P (1995) The European regional seas ecosystem model, a complex marine ecosystem model. Neth J Sea Res 33:233-246

Bjørnsen PK (1986) Automatic determination of bacterioplankton biomass by image analysis. Appl Environ Microbiol 51:1199-1204

Bronk DA, See JH, Bradley P, Killberg L (2007) DON as a source of bioavailable nitrogen for phytoplankton. Biogeosciences 4:283-296

> Cloern JE (1996) Phytoplankton bloom dynamics in coastal ecosystems: a review with some general lessons from sustained investigation of San Francisco Bay, California. Rev Geophys 34:127-168

Cloern JE, Jassby AD (2008) Complex seasonal patterns of primary producers at the land-sea interface. Ecol Lett 11: 1294-1303

> Cózar A, Echevarría F (2005) Size structure of the planktonic community in microcosms with different levels of turbulence. Sci Mar 69:187-197

> Delgado M, Latasa M, Estrada M (1992) Variability in the size-fractionated distribution of the phytoplankton across the Catalan front of the North-West Mediterranean. J Plankton Res 14:753-771

- Dortch Q (1990) The interaction between ammonium and nitrate uptake in phytoplankton. Mar Ecol Prog Ser 61: 183-201

> Ducklow HW, Kirchman DL (1983) Bacterial dynamics and distribution during a spring diatom bloom in the Hudson River plume, USA. J Plankton Res 5:333-355

Ediger D, Tugrul S, Yilmaz A (2005) Vertical profiles of particulate organic matter and its relationship with chlorophyll-a in the upper layer of the NE Mediterranean Sea. J Mar Syst 55:311-326

> Eppley RW, Rogers JN, McCarthy JJ (1969) Half-saturation constants for uptake of nitrate and ammonium by marine phytoplankton. Limnol Oceanogr 14:912-920

> Estrada M, Alcaraz M, Marrasé C (1987) Effects of turbulence on the composition of phytoplankton assemblages in marine microcosms. Mar Ecol Prog Ser 38:267-281

- Estrada M, Marrasé C, Alcaraz M (1988) Phytoplankton response to intermittent stirring and nutrient additions in marine microcosms. Mar Ecol Prog Ser 48:225-234

Estrada M, Berdalet E, Vila M, Marrasé C (2003) Effects of pulsed nutrient enrichment on enclosed phytoplankton: ecophysiological and successional responses. Aquat Microb Ecol 32:61-71

European Environment Agency (EEA) (1999) State and pressures of the marine and coastal Mediterranean environment. Environmental Assessment Series No 5. EEA, Copenhagen

European Environment Agency (EEA) (2001) Eutrophication in Europe's coastal waters. Topic Report 7/2001. EEA, Copenhagen

Fasham MJR, Ducklow HW, McKelvie SM (1990) A nitrogen-based model of plankton dynamics in the oceanic mixed layer. J Mar Res 48:591-639

> Gasol JM, del Giorgio PA (2000) Using flow cytometry for counting natural planktonic bacteria and understanding the structure of planktonic bacterial communities. Sci Mar 64:197-224

Guadayol Ò, Peters F (2006) Analysis of wind events in a coastal area: a tool for assessing turbulence variability for studies on plankton. Sci Mar 70:9-20

Guadayol Ò, Marrasé C, Peters F, Berdalet E, Roldán C, Sabata A (2009) Responses of coastal osmotrophic planktonic communities to simulated events of turbulence and nutrient load throughout a year. J Plankton Res 31: 583-600

Hansen HP, Koroleff F (1999) Determination of nutrients. In: Grasshoff K, Kremling K, Ehrhardt M (eds) Methods of seawater analysis. Wiley-Verlag Chemie, Weinheim, p 159-228

> Horne EPW, Loder JW, Naimie CE, Oakey NS (1996) Turbulence dissipation rates and nitrate supply in the upper water column on Georges Bank. Deep-Sea Res II 43: 1683-1712

> Howarth RW, Butler T, Lunde K, Swaney D, Chu CR (1993) Turbulence and planktonic nitrogen-fixation: a mesocosm experiment. Limnol Oceanogr 38:1696-1711

> Iversen KR, Primicerio R, Larsen A, Egge JK and others (2010) Effects of small-scale turbulence on lower trophic levels under different nutrient conditions. J Plankton Res 32:197-208

Karp-Boss L, Boss E, Jumars PA (1996) Nutrient fluxes to planktonic osmotrophs in the presence of fluid motion. Oceanogr Mar Biol Annu Rev 34:71-107

> Kiørboe T, Saiz E (1995) Planktivorous feeding in calm and turbulent environments, with emphasis on copepods. Mar Ecol Prog Ser 122:135-145

> Kirchman D, Soto Y, Van Wambeck F, Bianchi M (1989) Bacterial production in the Rhône River plume: effect of mixing on relationships among microbial assemblages. Mar 
Ecol Prog Ser 53:267-275

Kokkinakis SA, Wheeler PA (1988) Uptake of ammonium and urea in the northeast Pacific: comparison between netplankton and nanoplankton. Mar Ecol Prog Ser 43: 113-124

Lancelot C, Spitz Y, Gypens N, Ruddick K and others (2005) Modelling diatom and Phaeocystis blooms and nutrient cycles in the Southern Bight of the North Sea: the MIRO model. Mar Ecol Prog Ser 289:63-78

Lazier JRN, Mann KH (1989) Turbulence and the diffusive layers around small organisms. Deep-Sea Res A 36: 1721-1733

> Le Bouteiller A (1986) Environmental control of nitrate and ammonium uptake by phytoplankton in the Equatorial Atlantic Ocean. Mar Ecol Prog Ser 30:167-179

Lévy M (2008) The modulation of biological production by oceanic mesoscale turbulence. Lect Notes Phys 744: 219-261

Liquete C, Canals M, Lastras G, Amblas D and others (2007) Long-term development and current status of the Barcelona continental shelf: a source-to-sink approach. Cont Shelf Res 27:1779-1800

Llasat MC, Puigcerver M (1997) Total rainfall and convective rainfall in Catalonia, Spain. Int J Climatol 17:1683-1695

> Lomas MW, Glibert PM (1999) Temperature regulation of nitrate uptake: a novel hypothesis about nitrate uptake and reduction in cool-water diatoms. Limnol Oceanogr 44:556-572

Longhurst A (1995) Seasonal cycles of pelagic production and consumption. Prog Oceanogr 36:77-167

Malits A, Peters F, Bayer-Giraldi M, Marrasé C, Zoppini A, Guadayol Ò, Alcaraz M (2004) Effects of small-scale turbulence on bacteria: a matter of size. Microb Ecol 48: 287-299

Margalef R (1978) Life-forms of phytoplankton as survival alternatives in an unstable environment. Oceanol Acta 1: 493-509

Martin-Vide J (1982) Características climatológicas de la precipitación en la franja costera mediterránea de la Península Ibérica. PhD thesis, Universitat de Barcelona

- Mercado JM, Ramírez T, Cortés D, Sebastián M, Liger E, Bautista B (2008) Partitioning the effects of changes in nitrate availability and phytoplankton community structure on relative nitrate uptake. Mar Ecol Prog Ser 359: 51-68

> Morel FMM, Hudson RJM, Price NM (1991) Limitation of productivity by trace metals in the sea. Limnol Oceanogr 36:1742-1755

Nerheim S, Stiansen JE, Svendsen H (2002) Grid-generated turbulence in a mesocosm experiment. Hydrobiologia 484:61-73

Nieto-Cid M, Álvarez-Salgado XA, Gago J, Pérez FF (2005) DOM fluorescence, a tracer for biogeochemical processes in a coastal upwelling system (NW Iberian Peninsula). Mar Ecol Prog Ser 297:33-50

> Peters F, Gross T (1994) Increased grazing rates of microplankton in response to small-scale turbulence. Mar Ecol Prog Ser 115:299-307

Peters F, Marrasé C, Gasol JM, Sala MM, Arin L (1998) Effects of turbulence on bacterial growth mediated through food web interactions. Mar Ecol Prog Ser 172: 293-303

Editorial responsibility: Graham Savidge, Portaferry, UK
Peters F, Marrasé C, Havskum H, Rassoulzadegan F, Dolan J, Alcaraz M, Gasol JM (2002) Turbulence and the microbial food web: effects on bacterial losses to predation and on community structure. J Plankton Res 24:321-331

> Peters F, Arin L, Marrasé C, Berdalet E, Sala MM (2006) Effects of small-scale turbulence on the growth of two diatoms of different size in a phosphorus-limited medium. J Mar Syst 61:134-148

> Petersen JE, Sanford LP, Kemp WM (1998) Coastal plankton responses to turbulent mixing in experimental ecosystems. Mar Ecol Prog Ser 171:23-41

> Porter KG, Feig YS (1980) The use of DAPI for identifying and counting aquatic microflora. Limnol Oceanogr 25: 943-948

> Riegman R, Noordeloos AAM (1998) Size-fractionated uptake of nitrogenous nutrients and carbon by phytoplankton in the North Sea during summer 1994. Mar Ecol Prog Ser 173:95-106

Riegman R, Flameling IA, Noordeloos AAM (1998) Sizefractionated uptake of ammonium, nitrate and urea and phytoplankton growth in the North Sea during spring 1994. Mar Ecol Prog Ser 173:85-94

Romero E (2010) Sources of plankton variability in an urbanized coastal ecosystem. PhD thesis, Universitat Politècnica de Catalunya - Consejo Superior de Investigaciones Científicas, Barcelona

Ruiz J, Macías D, Peters F (2004) Turbulence increases the average settling velocity of phytoplankton cells. Proc Natl Acad Sci USA 101:17720-17724

Satta MP, Agustí S, Mura MP, Vaqué D, Duarte CM (1996) Microplankton respiration and net community metabolism in a bay on the NW Mediterranean coast. Aquat Microb Ecol 10:165-172

Smetacek VS (1985) Role of sinking in diatom life-history cycles: ecological, evolutionary and geological significance. Mar Biol 84:239-251

> Stolte W, McCollin T, Noordeloos AAM, Riegman R (1994) Effect of nitrogen source on the size distribution within marine-phytoplankton populations. J Exp Mar Biol Ecol 184:83-97

Syrett PJ (1981) Nitrogen-metabolism of microalgae. Can Bull Fish Aquat Sci 210:182-210

- Thingstad TF, Skjoldal EF, Bohne RA (1993) Phosphorus cycling and algal-bacterial competition in Sandsfjord, western Norway. Mar Ecol Prog Ser 99:239-259

Thingstad TF, Krom MD, Mantoura RFC, Flaten GAF and others (2005) Nature of phosphorus limitation in the ultraoligotrophic Eastern Mediterranean. Science 309: 1068-1071

Utermöhl H (1958) Zur Vervollkommnung der quantitativen Phytoplankton-Methodik. Mitt Int Verein Limnol 9:1-38

Verity PG, Robertson CY, Tronzo CR, Andrews MG, Nelson JR, Sieracki ME (1992) Relationships between cell volume and the carbon and nitrogen content of marine photosynthetic nanoplankton. Limnol Oceanogr 37: 1434-1446

Wheeler PA, Kirchman DL (1986) Utilization of inorganic and organic nitrogen by bacteria in marine systems. Limnol Oceanogr 31:998-1009

Yentsch CS, Menzel DW (1963) A method for the determination of phytoplankton chlorophyll and phaeophytin by fluorescence. Deep-Sea Res 10:221-231

Submitted: October 28, 2011; Accepted: May 27, 2012

Proofs received from author(s): August 22, 2012 